\title{
The Molecular Composition of Hydrophilic Sulfur Sols Prepared by Acid Decomposition of Thiosulfate [1]
}

\author{
Ralf Steudel*, Thomas Göbel, and Gabriele Holdt \\ Institut für Anorganische und Analytische Chemie, Sekr. C2, Technische Universität Berlin, \\ D-1000 Berlin 12 \\ Z. Naturforsch. 43b, 203-218 (1988); received August 3, 1987 \\ Sulfur Sol, Polythionates, Elemental Sulfur, Thiosulfate Decomposition, Sulfur Bacteria \\ Hydrophilic sulfur sols prepared from sodium thiosulfate and concentrated sulfuric acid and \\ purified by repeated $\mathrm{NaCl}$ precipitation and peptization in water have been studied by chemical \\ analysis, vibrational spectroscopy, ion-pair chromatography and reversed-phase HPLC. The \\ composition of the sol is $\mathrm{Na}_{1.64} \mathrm{~S}_{28.6} \mathrm{O}_{6} \cdot 5.9 / n \mathrm{~S}_{n} \cdot 1.0 \mathrm{NaCl}$. The elemental sulfur $\mathrm{S}_{n}(n=6-14$; \\ mainly $\mathrm{S}_{8}$ ) accounts for $17 \%$ the total sulfur; $83 \%$ of the $\mathrm{S}$ are present as long-chain polythionates \\ which form micelles in which the $\mathrm{S}_{n}$ molecules are dissolved. On aging of the sol at $20{ }^{\circ} \mathrm{C}$ the \\ polythionate micelles decompose to give water-soluble short-chain polythionates and elemental \\ sulfur which precipitates from the solution. The micelle structure of hydrophilic sulfur sols may \\ serve as a model for the so-called sulfur globules $\left(\mathrm{S}^{0}\right)$ formed intra- or extracellularly by many \\ sulfur bacteria which oxidize reduced sulfur compounds to $S^{0}$. - Infrared and Raman spectra of \\ $\mathrm{K}_{2} \mathrm{~S}_{m} \mathrm{O}_{6}(m=3-6)$ are reported. The photodecomposition of aqueous tetrathionate yields sulfite, \\ thiosulfate, and polythionates with up to 9 sulfur atoms.
}

\section{Introduction}

Sulfur sols can be classified as hydrophobic or hydrophilic. Hydrophobic sulfur sols are prepared by pouring solutions of $\mathrm{S}_{8}$ in organic solvents like ethanol or acetone into water. The finely precipitated sulfur remains in a colloidal state for some time; these milky sols are usually termed Weimarn sols. They are neither very concentrated nor of high stability. The particles of this sol are hydrophobic, soluble in $\mathrm{CS}_{2}$, and most probably consist of $\mathrm{S}_{8}[2]$.

Hydrophilic sulfur sols can be prepared by two different routes. So-called Selmi sols are obtained by reaction of $\mathrm{SO}_{2}$ (or sulfites) with $\mathrm{H}_{2} \mathrm{~S}$ (or sulfides) in water, while the acid decomposition of sodium thiosulfate in water provies so-called Raffo sols which sometimes have also been termed as Oden or LaMer sols [2]. In this paper we are concerned with a thorough analytical characterization of Raffo sols; a corresponding investigation of Selmi sols will be published elsewhere.

The decomposition of sodium thiosulfates in aqueous acids has been studied numerous times [3] and the following reaction products have been identified, the relative importance of which depends on the reaction conditions: elemental sulfuir $\left(\mathrm{S}_{8}, \mathrm{~S}_{7}, \mathrm{~S}_{6}\right.$ [4-7]), polythionates $\mathrm{S}_{m} \mathrm{O}_{6}{ }^{2-}[8-11]$, sulfate [3], $\mathrm{SO}_{2}$ [3], and $\mathrm{H}_{2} \mathrm{~S}$ [3]. The colloidal sulfur [12] is isolated

\footnotetext{
* Reprint requests to Prof. Dr. R. Steudel.

Verlag der Zeitschrift für Naturforschung, D-7400 Tübingen 0932-0776/88/0200-0203/\$01.00/0
}

and purified by repeated precipitation by $\mathrm{NaCl}$ followed by either filtration or centrifugation and repeptization in water. In this way a clear solution of hydrophilic sulfur is obtained with a particle size of ca. $0.1-0.2 \mu \mathrm{m}[13,14]$. Freshly prepared sols are free of lower polythionates $(m=3-6)$ [8] but after standing at $20^{\circ} \mathrm{C}$ for some hours or days (aging) the mentioned polythionates can be detected in the aqueous phase (after precipitation of the sol by $\mathrm{NaCl}$ ); at the same time elemental sulfur precipitates from the solution and slowly crystallizes as $\alpha-\mathrm{S}_{8}$ $[2,8,9]$.

The freshly prepared sol particles are negatively charged and can be precipitated by a number of cations the efficiency of which increases with increasing ionic charge $\left(\mathrm{Na}^{+}<\mathrm{Ca}^{2+}<\mathrm{Al}^{3+}\right.$ etc. $)[2,8,9]$. Only with $\mathrm{HCl}, \mathrm{LiCl}$ and $\mathrm{NaCl}$ a reversible precipitation is achieved [9]. The solubility of hydrophilic sulfur increases rapidly with temperature [15]; $\mathrm{NaOH}, \mathrm{NH}_{3}$ and thiosulfate destroy the sol with sulfur precipitation $[2,9]$.

It has been suspected that the sol particles consist of elemental (polymeric) sulfur covered and peptized by lower polythionates $(m=3-6)[8,9]$, but Weitz et al. [16] argued that the properties of Raffo sols can be explained by the assumption that long-chain polythionates $(m=40-140)$ and no elemental sulfur are present. However, no direct evidence for the presence of polythionates with $m>6$ in Raffo sols has so far been presented. Therefore, we have extensively analyzed these sols by reversed-phase high-pressure 
liquid chromatography (HPLC) as well as ion chromatography (IC) to search for homocyclic sulfur molecules $\mathrm{S}_{n}(n=6,7,8 \cdots 30)$ and polythionates $\mathrm{S}_{m} \mathrm{O}_{6}{ }^{2-}(m=3,4 \cdots 25)$ which can be detected and determined by these techniques [17-20] unless the ring size $n$ exceeds 30 atoms or the chain-length is more than 25 atoms. No direct analytical methods are available at present for these large molecules and ions, respectively.

\section{Preparation and Properties of Raffo sols}

Within $15 \mathrm{~min}$ an aqueous solution of sodium thiosulfate $(3 \mathrm{~mol} / \mathrm{l} ; 30 \mathrm{ml})$ is added dropwise with stirring to concentrated sulfuric acid $(96 \% ; 10 \mathrm{ml})$ resulting in heat generation $\left(70-80^{\circ} \mathrm{C}\right)$, evolution of $\mathrm{SO}_{2}$ and some $\mathrm{H}_{2} \mathrm{~S}$, and formation of a yellow precipitate. The mixture is cooled in an ice-bath to $0{ }^{\circ} \mathrm{C}$ for $30 \mathrm{~min}$, and $50 \mathrm{ml}$ of a saturated sodium chloride solution $\left(20^{\circ} \mathrm{C}\right)$ are added to complete the precipitation. After $15 \mathrm{~min}$ the yellow solid is isolated by centrifugation and careful decantation of the aqueous phase.
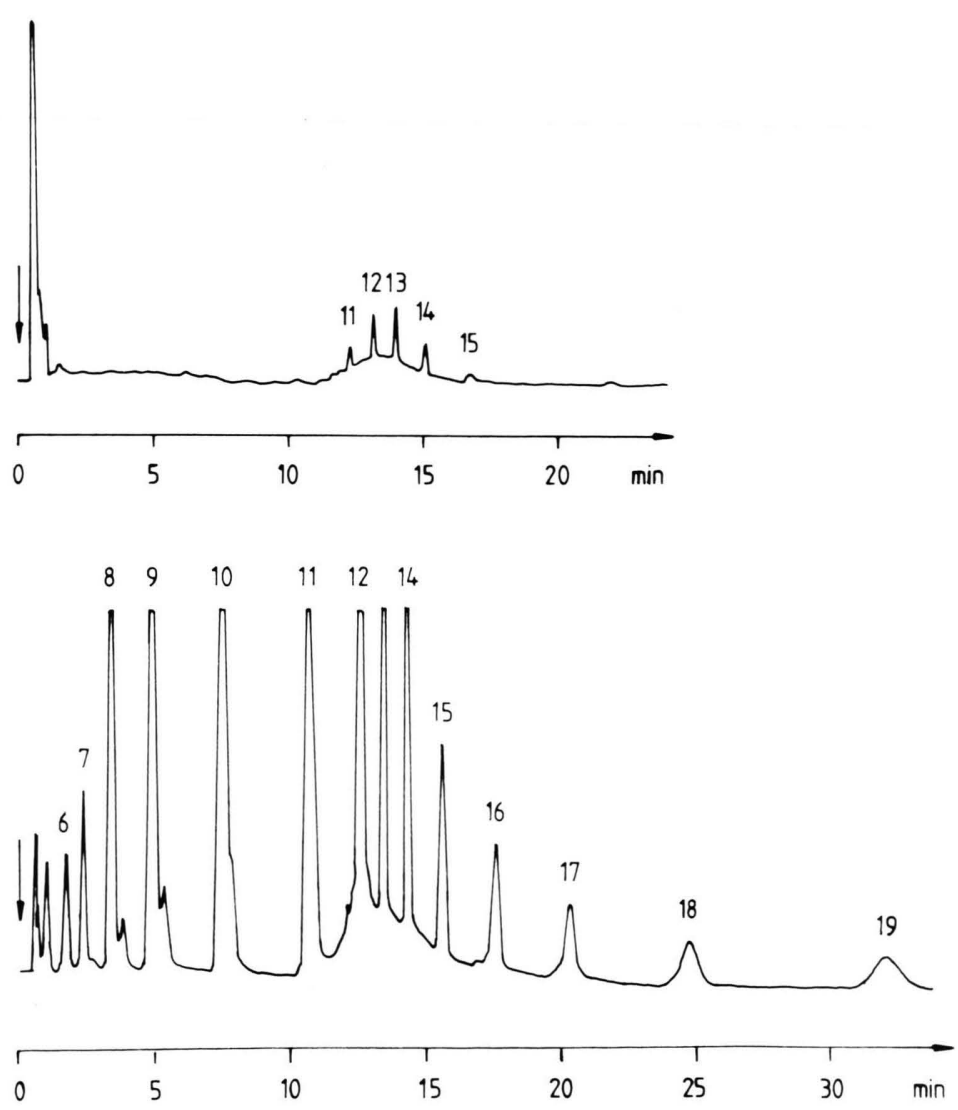

For purification [16] the precipitate is suspended in $200 \mathrm{ml} \mathrm{H}_{2} \mathrm{O}$ and the unsoluble part removed by centrifugation $(10 \mathrm{~min})$. To the greenish-yellow aqueous phase containing the colloidal sulfur are added $50 \mathrm{ml}$ of a saturated aqueous $\mathrm{NaCl}$ solution whereupon the sol is precipitated. Centrifugation, peptization in $200 \mathrm{ml} \mathrm{H}_{2} \mathrm{O}$ followed by precipitation by $\mathrm{NaCl}$ are repeated 10 times. Resuspending the precipitate thus obtained in $200 \mathrm{ml} \mathrm{H}_{2} \mathrm{O}$ results in a light-yellow opalescend clear solution of $\mathrm{pH} \approx 6$ which after dilution shows a Tyndall effect. This purified sol which does not smell after $\mathrm{SO}_{2}$ has been used for all of the following experiments.

Investigation of the sol by ion-pair chromatography (IC) $[19,20]$ showed that thiosulfate and lower polythionates $\mathrm{S}_{m} \mathrm{O}_{6}{ }^{2-}(m=4-10)$ were absent (see Fig. 1a) in contrast to te original thiosulfate-sulfuric acid mixture which contained all of these species and which smelled strongly after $\mathrm{SO}_{2}$.

When $20 \mathrm{ml}$ of freshly prepared Raffo sol were evaporated to dryness in a vacuum at $45-50{ }^{\circ} \mathrm{C}$ bath temperature followed by drying in an evacuated de-
Fig. 1. Ion-pair chromatogram of a freshly prepared Raffo sol (a: above) and of the same sol after aging for $36 \mathrm{~h}$ at $20^{\circ} \mathrm{C}$ (b: below) showing the formation of thiosulfate (first peak) and of lower polythionates $\mathrm{S}_{m} \mathrm{O}_{6}{ }^{2-}(m=5-19)$. The ordinate gives the $\mathrm{UV}$ absorbance at $240 \mathrm{~nm}$. Eluent: $30 \% \mathrm{CH}_{3} \mathrm{CN}, 70 \% \mathrm{H}_{2} \mathrm{O}$. The additional peaks neighboring the peaks due to $\mathrm{S}_{8} \mathrm{O}_{6}{ }^{2-}$ and $\mathrm{S}_{9} \mathrm{O}_{6}{ }^{2-}$ are caused by overloading of the column (see "Experimental"). 
siccator over $\mathrm{P}_{2} \mathrm{O}_{5}$ for 3-5 days, a yellow, in parts shiny and flaky residue $(159.2 \mathrm{mg}$ ) was obtained the composition of which corresponded to the "formula" $\mathrm{Na}_{1.64} \mathrm{~S}_{34.5} \mathrm{O}_{6} \cdot 1.0 \mathrm{NaCl}(85.3 \%$ S, $2.9 \% \mathrm{Na}, 2.7 \%$ $\mathrm{Cl}$, no $\mathrm{H})$. Sulfur was determined after bromine oxidation as sulfate by titration; combustion and gaschromatographic analysis did not show any $\mathrm{C}$ or $\mathrm{H}$; heating of the flaky residue in air to $600{ }^{\circ} \mathrm{C}$ for 60-90 min resulted in a colorless mixture of $\mathrm{Na}_{2} \mathrm{SO}_{4}$ and $\mathrm{NaCl}(13.4 \%$ of the original weight $)$ the $\mathrm{Cl}$ con- tent of which was determined by argentometric titration thus yielding the $\mathrm{NaCl}$ value $(4.47 \%)$. The remaining weight $(8.9 \%)$ must have been $\mathrm{Na}_{2} \mathrm{SO}_{4}$ originating from the oxidation of sodium polythionate resulting in a total $\mathrm{Na}$ content of $2.9 \%$. The missing $7.4 \%$ of the evaporation residue were interpreted as oxygen.

The presence of oxygen in the form of $-\mathrm{SO}_{3}{ }^{-}$ groups was confirmed by the infrared spectrum of the flaky evaporation residue which showed strong
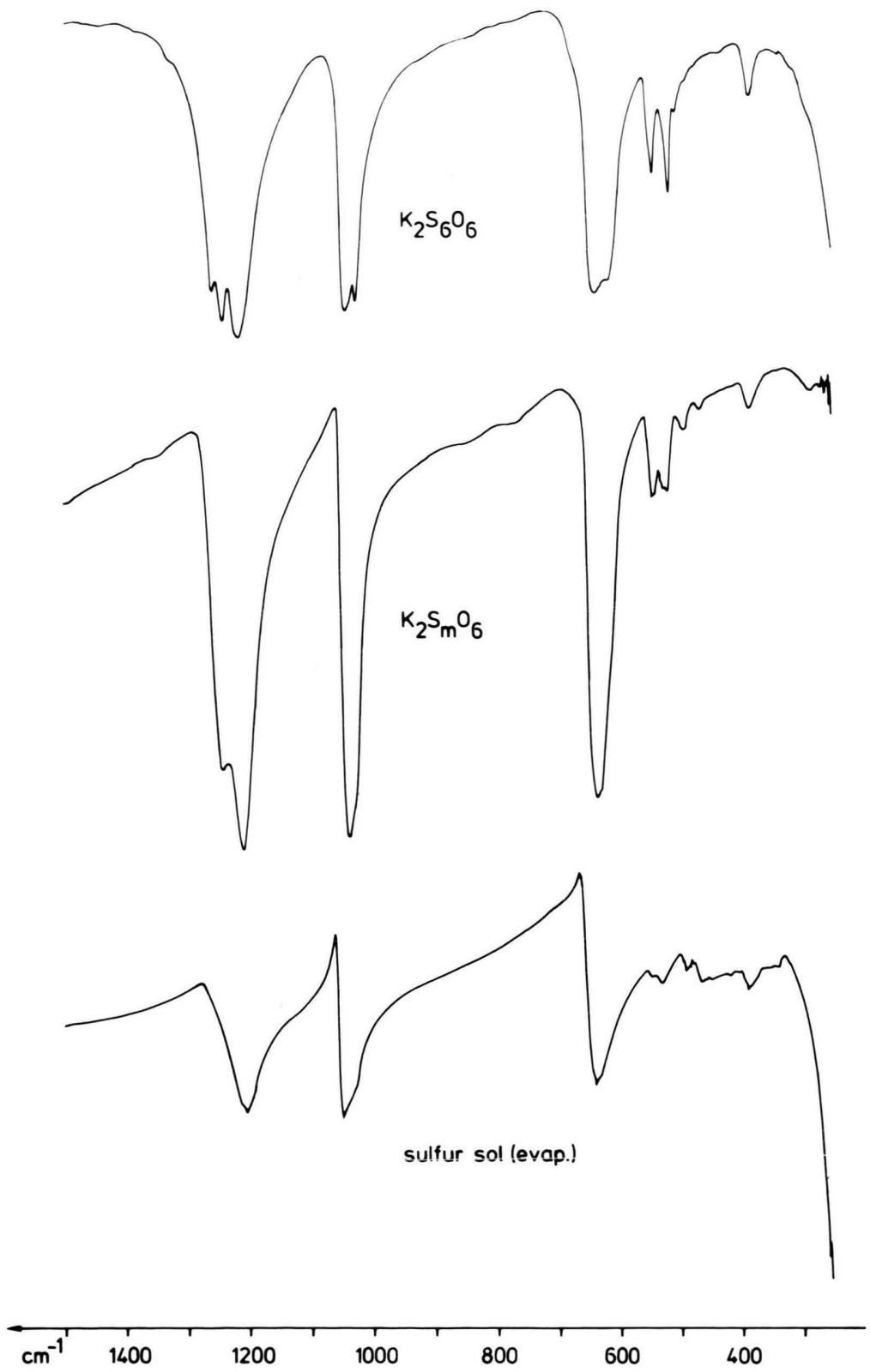

Fig. 2. Infrared spectrum of an evaporated Raffo sol ( $\mathrm{KBr}$ disc), and of $\mathrm{K}_{2} \mathrm{~S}_{6} \mathrm{O}_{6}$ and a polythionate mixture " $\mathrm{K}_{2} \mathrm{~S}_{m} \mathrm{O}_{6}(15<m<40)$ " after Weitz et al. [24]. For wavenumbers see Table I. 
but broad absorptions at 1205, 1050-1030 and $640 \mathrm{~cm}^{-1}$ and weak bands at 525,460 and $385 \mathrm{~cm}^{-1}$ ( $\mathrm{KBr}$ disc; see Fig. 2) which all are typical for

polythionates as a comparison with the spectra of various polythionates in Fig. 2 and 3 shows (see also ref. [21]).
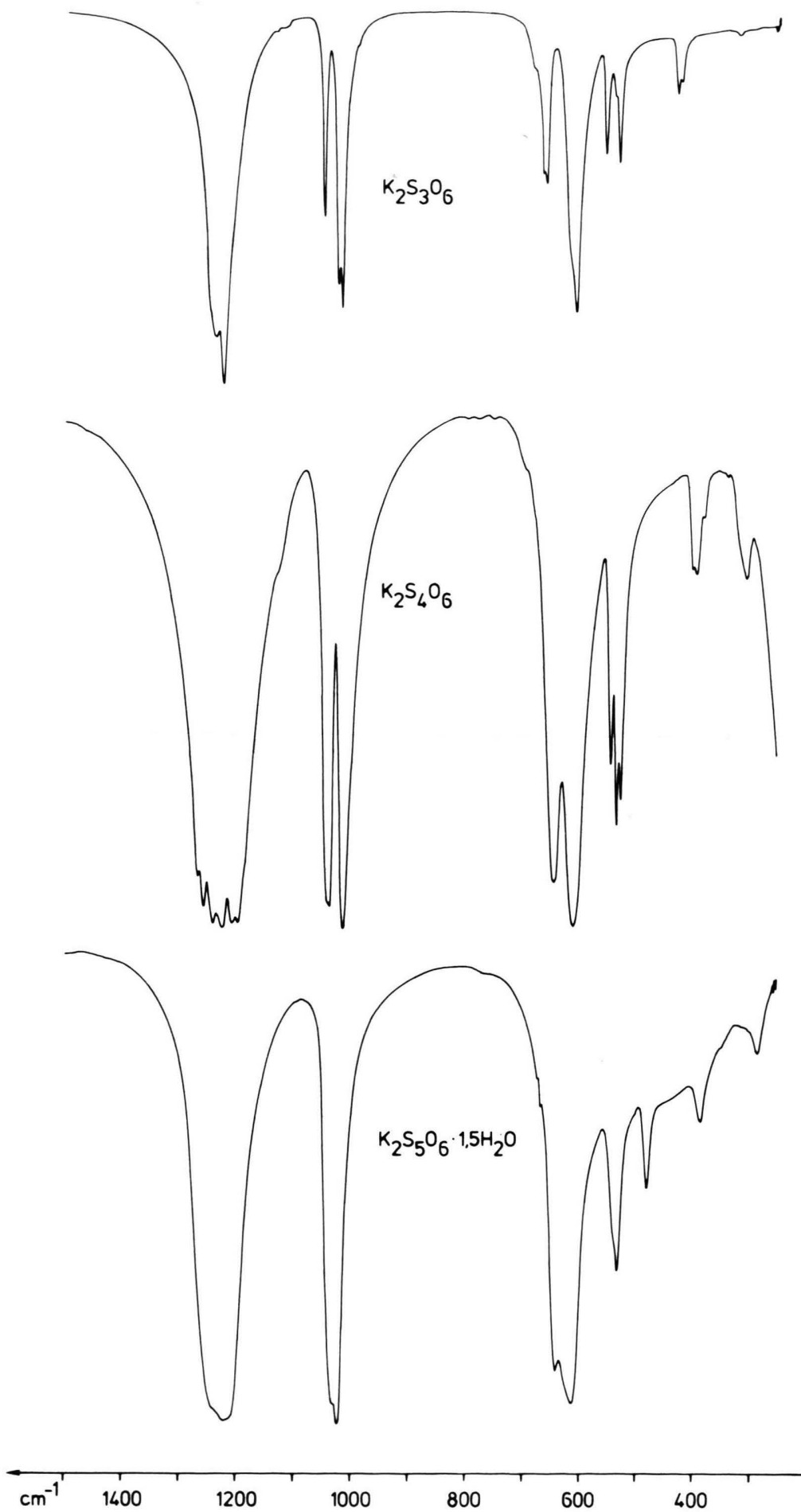

Fig. 3. Infrared spectra ( $\mathrm{KBr}$ discs) of $\mathrm{K}_{2} \mathrm{~S}_{3} \mathrm{O}_{6}, \mathrm{~K}_{2} \mathrm{~S}_{4} \mathrm{O}_{6}$, and $\mathrm{K}_{2} \mathrm{~S}_{5} \mathrm{O}_{6} \cdot 1.5 \mathrm{H}_{2} \mathrm{O}$. For wavenumbers see Table I. 
Both the aqueous Raffo sol and the evaporation residue were investigated by Raman spectroscopy. The lines observed for the solid at 471, 437, 393, 244, $217,150,80,48$ and $40 \mathrm{~cm}^{-1}$ can all be assigned to $S_{8}$ [22] excepting the $393 \mathrm{~cm}^{-1}$ signal which is a typical line of polythionates and also observed in the case of $\mathrm{K}_{2} \mathrm{~S}_{4} \mathrm{O}_{6}$ and $\mathrm{K}_{2} \mathrm{~S}_{5} \mathrm{O}_{6}$ (see Fig. 4 and [23]). Most probably this line represents the stretching mode of a weak SS bond like the one neighboring to the $\mathrm{SO}_{3}{ }^{-}$ group. The aqueous sol itself showed only lines at

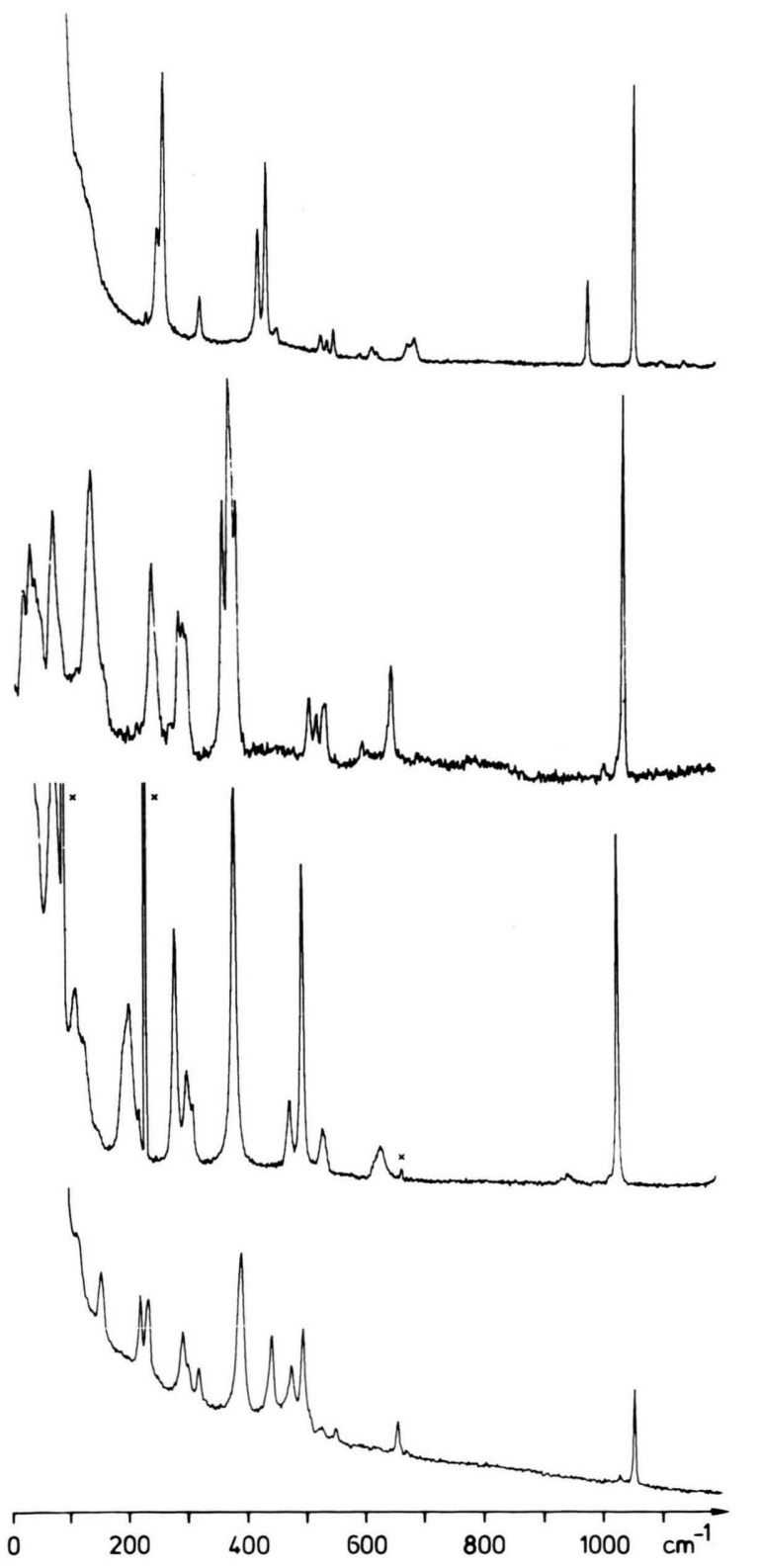

471,217 and $149 \mathrm{~cm}^{-1}$ (Fig. 2) which are identical with the strongest Raman signals of the $\mathrm{S}_{8}$ molecule [22], although other sulfur-rich species like polythionates seem to contribute to the $471 \mathrm{~cm}^{-1}$ line too.

$\mathrm{X}$-ray powder diagrams of the evaporation residue of the Raffo sol and of the freshly precipitated sol (by $\mathrm{NaCl}$ ) revealed only lines typical for $\alpha-\mathrm{S}_{8}$ and $\mathrm{NaCl}$ $\left(\mathrm{CuK}_{\alpha}\right.$ radiation, $40 \mathrm{kV}$, exposure time $6 \mathrm{~h}$ at $\left.20^{\circ} \mathrm{C}\right)$.

Since the Raman spectra of the Raffo sol indicated

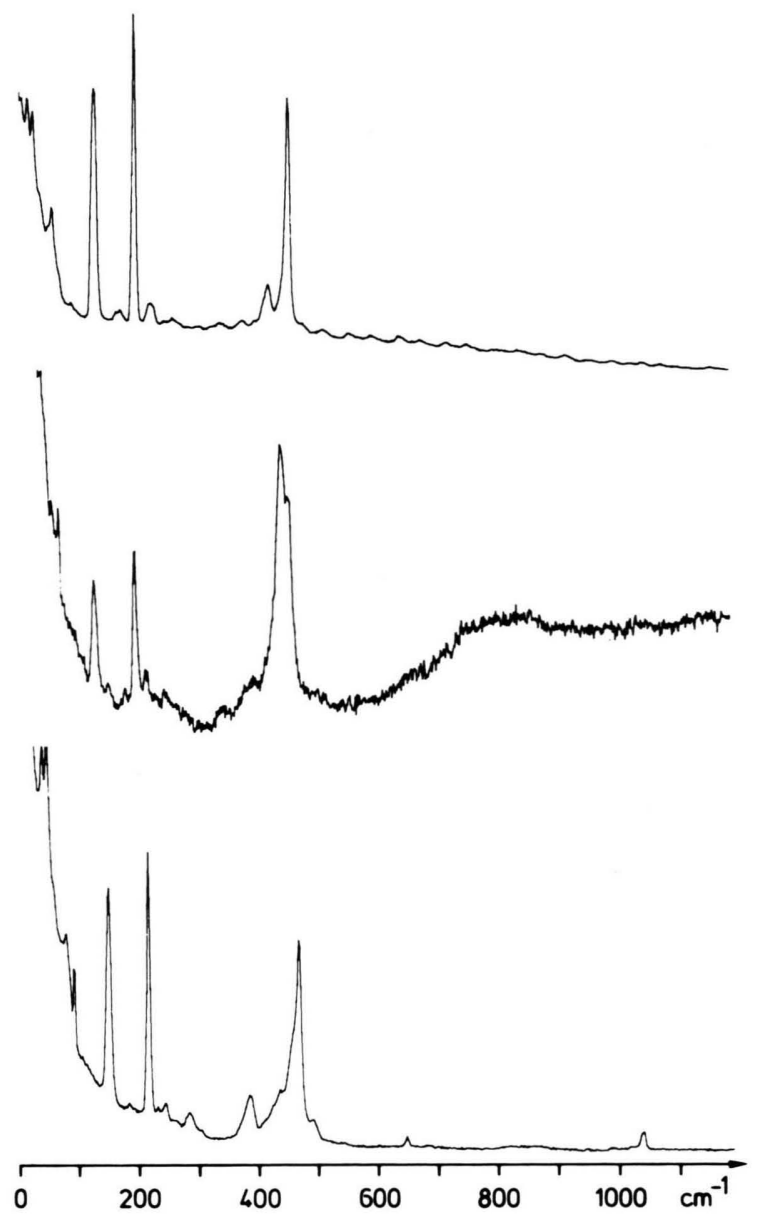

Fig. 4. Left: Raman spectra of $\mathrm{K}_{2} \mathrm{~S}_{3} \mathrm{O}_{6}, \quad \mathrm{~K}_{2} \mathrm{~S}_{4} \mathrm{O}_{6}$, $\mathrm{K}_{2} \mathrm{~S}_{5} \mathrm{O}_{6} \cdot 1.5 \mathrm{H}_{2} \mathrm{O}$, and $\mathrm{K}_{2} \mathrm{~S}_{6} \mathrm{O}_{6}$ (from top to bottom). The lines marked by $\mathrm{x}$ are caused by the krypton laser. For wavenumbers see Table II. Right: Raman spectra of a wet sulfur sol precipitated by $\mathrm{NaCl}$ (top), of an evaporated sulfur sol (center) and of a polythionate mixture " $\mathrm{K}_{2} \mathrm{~S}_{m} \mathrm{O}_{6}$ $(15<m<40)$ " after Weitz et al. [24] (bottom). 
the presence of $\mathrm{S}_{8}$, a reversed-phase HPLC analysis was carried out using octadecylsilane as a stationary phase and methanol as mobile phase $[17,18]$. The freshly prepared and filtered sol was diluted (1:25) and directly introduced into the loop injector of the chromatograph.

The results presented in Fig. 5 and Table III demonstrate the presence of elemental sulfur $\mathrm{S}_{n}$ but in addition to $\mathrm{S}_{8}$ molecules other sulfur rings are present too. The order of decreasing concentrations is $\mathrm{S}_{8}>\mathrm{S}_{7}>\mathrm{S}_{6}>\mathrm{S}_{9}>\mathrm{S}_{12}>\mathrm{S}_{10}, \mathrm{~S}_{11}, \mathrm{~S}_{13}, \mathrm{~S}_{14}, \mathrm{~S}_{15}$. Using empirical calibration functions [18] the exact concentrations of four species have been determined as follows (in mg/l): $\mathrm{S}_{6} 6.14, \mathrm{~S}_{7} 9.92, \mathrm{~S}_{8} 27.58, \mathrm{~S}_{12}$ 0.22 . Using these data the sum of all $\mathrm{S}_{n}$ concentrations can be estimated from Fig. 5 as $45 \mathrm{mg} / \mathrm{l}$. Consequently, $20 \mathrm{ml}$ of the undiluted Raffo sol prepared as described above contain about $22.5 \mathrm{mg}$ of elemental sulfur $\mathrm{S}_{n}(n=6-15)$. Since the total sulfur content of the sol ( $85 \%$ of the dry-mass of $159.2 \mathrm{mg}$ ) has been found as $135.7 \mathrm{mg}$, most of the sulfur (113 mg or $83 \%$ ) must be present in a form other than elemental!
678

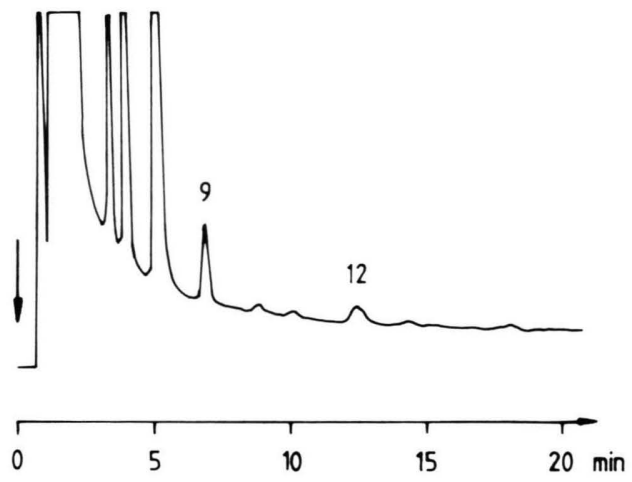

Fig. 5. HPLC analysis of a freshly prepared Raffo sol showing the presence of the sulfur homocycles $\mathrm{S}_{n}(n=$ 6-12). The strongest peak near $1.5 \mathrm{~min}$ is caused by polythionates. Eluent: $\mathrm{CH}_{3} \mathrm{OH}$. The ordinate gives the UV absorbance at $254 \mathrm{~nm}$.

The yellow flaky evaporation residue of the Raffo sol dissolved to a large extend in carbon disulfide on stirring for 4-6 h. On HPLC analysis the solution obtained showed all sulfur srings $\mathrm{S}_{\mathrm{n}}$ with $n=6-17$.

Table I. Infrared spectra of a Raffo sulfur sol and of various polythionates in the region $250-1400 \mathrm{~cm}^{-1}$ (wavenumbers in $\mathrm{cm}^{-1}$; relative intensities: vs $=$ very strong, $\mathrm{s}=$ strong, $\mathrm{m}=$ medium, $\mathrm{w}=$ weak, $\mathrm{vw}=$ very weak, $\mathrm{b}=\mathrm{broad}, \mathrm{sh}=\mathrm{shoulder}$ ) No anion absorptions were observed above $1400 \mathrm{~cm}^{-1}$.

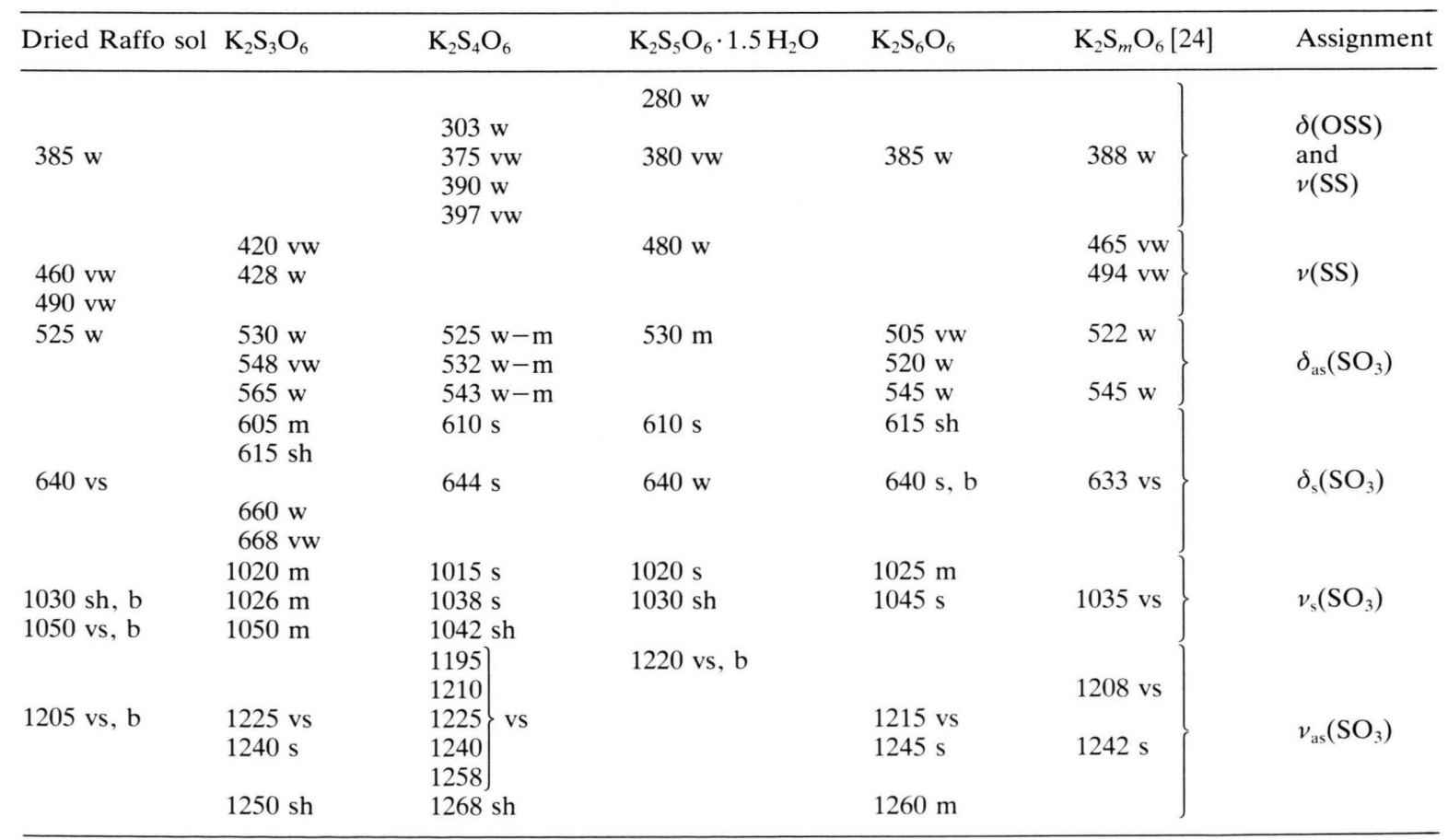




\begin{tabular}{|c|c|c|c|c|c|c|}
\hline \multicolumn{2}{|c|}{$\begin{array}{l}\text { Raffo sol } \\
\text { wet dry }\end{array}$} & \multirow[t]{2}{*}{$\mathrm{K}_{2} \mathrm{~S}_{3} \mathrm{O}_{6}$} & \multirow[t]{2}{*}{$\mathrm{K}_{2} \mathrm{~S}_{4} \mathrm{O}_{6}$} & \multirow[t]{2}{*}{$\mathrm{K}_{2} \mathrm{~S}_{5} \mathrm{O}_{6} \cdot 1.5 \mathrm{H}_{2} \mathrm{O}$} & \multirow[t]{2}{*}{$\mathrm{K}_{2} \mathrm{~S}_{6} \mathrm{O}_{6}$} & $\mathrm{~K}_{2} \mathrm{~S}_{m} \mathrm{O}_{6}[24]$ \\
\hline & $41 \mathrm{w}$ & & & & & $39 \mathrm{~s}$ \\
\hline & $48 w$ & $58 \mathrm{~s}$ & & & $48 w$ & $47 \mathrm{~s}$ \\
\hline & $80 \mathrm{w}$ & & & $74 \mathrm{~m}, \mathrm{~b}$ & & $80 \mathrm{~m}$ \\
\hline & & & & $114 \mathrm{~m}, \mathrm{~b}$ & $112 \mathrm{w}$ & \\
\hline \multirow[t]{3}{*}{$149 \mathrm{~m}$} & $150 \mathrm{vs}$ & & 153 vs & & $153 \mathrm{~m}$ & 150 vs \\
\hline & $194 \mathrm{w}$ & & & & & $183 \mathrm{vw}$ \\
\hline & & & & $206 \mathrm{~s}, \mathrm{~b}$ & & \\
\hline \multirow[t]{7}{*}{$217 \mathrm{~m}$} & 217 vs & & & & $220 \mathrm{~m}$ & $216 \mathrm{vs}$ \\
\hline & $244 \mathrm{w}$ & & & & $233 \mathrm{~m}$ & $243 \mathrm{w}$ \\
\hline & & $251 \mathrm{~m}$ & $255 \mathrm{~s}$ & & & \\
\hline & & $\begin{array}{l}262 \mathrm{~s} \\
325 \mathrm{w}\end{array}$ & $300 \mathrm{~s}, \mathrm{~b}$ & $\begin{array}{l}284 \mathrm{~s} \\
303 \mathrm{~m}\end{array}$ & $\begin{array}{l}291 \mathrm{~m} \\
299 \mathrm{sh}\end{array}$ & $284 \mathrm{w}$ \\
\hline & & & $374 \mathrm{~m}$ & & $318 \mathrm{w}$ & \\
\hline & & & $\begin{array}{l}384 \mathrm{~s} \\
396 \mathrm{~m}\end{array}$ & 384 vs & $389 \mathrm{~s}$ & $384 \mathrm{~m}, \mathrm{~b}$ \\
\hline & $438 \mathrm{~m}$ & $\begin{array}{l}443 \mathrm{~m} \\
455 \mathrm{~s}\end{array}$ & & & $440 \mathrm{~m}$ & $\begin{array}{l}438 \mathrm{vw} \\
450 \mathrm{sh}\end{array}$ \\
\hline \multirow{10}{*}{$\begin{array}{l}471 \mathrm{~s} \\
476 \mathrm{sh}\end{array}$} & 472 vs & & & $477 \mathrm{~m}$ & $472 \mathrm{~m}$ & 470 vs \\
\hline & & & $518 \mathrm{~m}$ & $501 \mathrm{~s}$ & & $494 \mathrm{w}$ \\
\hline & & $530 \mathrm{vw}$ & & $534 \mathrm{~m}$ & $524 \mathrm{w}$ & \\
\hline & & $542 \mathrm{vw}$ & $546 \mathrm{~m}$ & & $550 \mathrm{w}$ & \\
\hline & & $552 \mathrm{vw}$ & & $636 \mathrm{~m}$ h & & \\
\hline & & & $657 \mathrm{~m}$ & & $655 \mathrm{w}$ & $651 \mathrm{vw}$ \\
\hline & & $680 \mathrm{w}$ & & & & \\
\hline & & $692 \mathrm{w}$ & & & & \\
\hline & & $984 \mathrm{~m}$ & & 948 w & $1040 \mathrm{vw}$ & \\
\hline & & 1062 vs & $1045 \mathrm{~s}$ & 1037 vs & $1053 \mathrm{~m}$ & $1047 \mathrm{w}$ \\
\hline
\end{tabular}

Table II. Raman spectra of wet and dry Raffo sols and of various polythionates in the region $20-1200 \mathrm{~cm}^{-1}$ (wavenumbers in $\mathrm{cm}^{-1}$; definition of intensities as in Table I).
The areas of the chromatographic peaks decreased in the order $\mathrm{S}_{8} \gg \mathrm{S}_{7} \gg \mathrm{S}_{12}>\mathrm{S}_{6}>\mathrm{S}_{9}>\mathrm{S}_{15}>\mathrm{S}_{10}, \mathrm{~S}_{14}, \mathrm{~S}_{16}$, $\mathrm{S}_{17}>\mathrm{S}_{11}, \mathrm{~S}_{13}$. The peak areas of $\mathrm{S}_{8}$ and $\mathrm{S}_{7}$ accounted for $92 \%$ of the sum of all peak areas (Fig. 6).

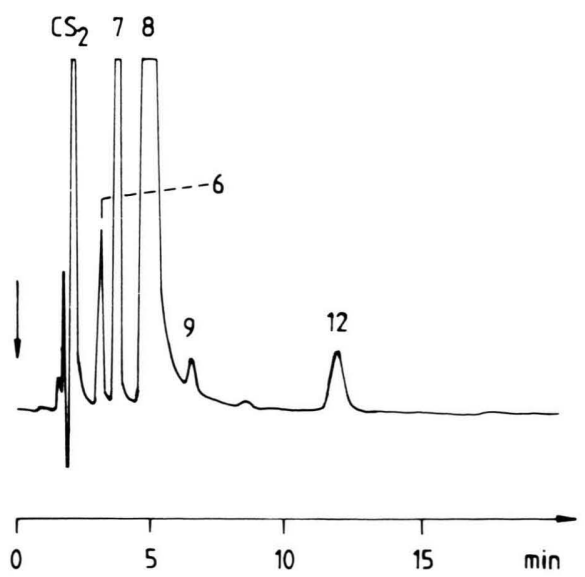

Fig. 6. HPLC analysis of an $\mathrm{CS}_{2}$ extract of the evaporated Raffo sol showing the presence of $\mathrm{S}_{6}, \mathrm{~S}_{7}, \mathrm{~S}_{8}, \mathrm{~S}_{9}, \mathrm{~S}_{10}$, and $\mathrm{S}_{12}$. Eluent: $\mathrm{CH}_{3} \mathrm{OH}$. The ordinate gives the UV absorbance at $254 \mathrm{~nm}$.
Table III. HPLC analysis of a freshly prepared Raffo sol $(\mathrm{t}=0 \mathrm{~h})$ and of the same sol after aging for $18 \mathrm{~h}$ and $45 \mathrm{~h}$, respectively $\left(t_{R}=\right.$ retention time; $c_{i}=$ concentration of species $\mathrm{i}$; death time $1.21 \mathrm{~min}$ ).

\begin{tabular}{llllll}
\hline & & $\mathrm{S}_{6}$ & $\mathrm{~S}_{7}$ & $\mathrm{~S}_{8}$ & $\mathrm{~S}_{12}$ \\
& $\mathrm{t}_{\mathrm{R}}(\mathrm{min})$ & 3.24 & 3.82 & 5.04 & 12.38 \\
\hline $\mathrm{t}=0$ & $\mathrm{c}_{\mathrm{i}}(\mathrm{mg} / \mathrm{l})$ & 6.14 & 9.92 & 27.58 & 0.22 \\
$\mathrm{t}=18 \mathrm{~h}$ & $\mathrm{c}_{\mathrm{i}}(\mathrm{mg} / \mathrm{l})$ & 2.91 & 7.09 & 25.94 & 0.20 \\
$\mathrm{t}=45 \mathrm{~h}$ & $\mathrm{c}_{\mathrm{i}}(\mathrm{mg} / \mathrm{l})$ & - & 3.34 & 16.03 & 0.19 \\
\hline
\end{tabular}

\section{Aging of Raffo sols}

Hydrophilic sulfur sols are thermodynamically unstable both with respect to interconversion reactions resulting in stable species like $\mathrm{S}_{8}$ and with respect to hydrolytic reactions with the solvent. We have therefore studied extensively the change in molecular composition on standing at $20^{\circ} \mathrm{C}$ as well as on extraction with organic solvents.

On standing of Raffo sols for several days at $20^{\circ} \mathrm{C}$ pale-yellow flakes precipitated and settled on the bottom of the vessel. This sulfur-like material did not 
show peptization in a large excess of water and dissolved only partly in $\mathrm{CS}_{2}$ the solution containing $\mathrm{S}_{8}$ $(98 \%), S_{7}(1.9 \%)$ and traces of $S_{9}$ and $S_{6}$. Basically the same result was obtained on extraction of the precipitate with methanol and subsequent HPLC analysis.

To study the time-dependend composition change two types of experiments were performed:

a) the sol was stirred at $20^{\circ} \mathrm{C}$ and at certain time intervals was analyzed for polythionates by IC and for elemental sulfur by HPLC,

b) the sol was stirred with either cyclohexane (upper layer) or carbon disulfide (lower layer) to continuously extract elemental sulfur, and the organic layer was analyzed for $S_{n}$ by HPLC and the aqueous phase for $\mathrm{S}_{m} \mathrm{O}_{6}{ }^{2-}$ by IC.

Type a) experiments showed that the concentration of polythionates $\mathrm{S}_{m} \mathrm{O}_{6}{ }^{2-}(m=5-10)$ increased from nothing to considerable values after $88.5 \mathrm{~h}$ (see Table IV and Fig. 1b). The concentration of penta-, hexa-, hepta- and octathionate increased steadily, while that of the higher polythionates $(m=9-14)$ went through a maximum followed by a definite decrease after 3 days. When the stirring was continued for 8 days, the concentrations of hepta- and octathionate also started to decrease and only those of penta- and hexathionate went further up. Tetrathionate was also formed but its concentration remained low at all times; the same holds for thiosulfate. Simultaneously the flaky sulfur-rich precipitate appeared which has already been mentioned above. The $\mathrm{pH}$ value of $c a$. 5.6 did not change within 5 days.

HPLC analysis of the Raffo sol after aging for 18 and $45 \mathrm{~h}$, respectively, resulted in lower values for

Table IV. Ion-chromatographic analysis of Raffo sols after aging at $20^{\circ} \mathrm{C}$ for up to $88.5 \mathrm{~h}$. Given are the chromatographic peak areas in arbitrary units.

\begin{tabular}{llllll}
\hline \multicolumn{7}{c}{ Aging time (h) } & & & \\
& 20.5 & 42.5 & 44.5 & 64.5 & 88.5 \\
\hline $\mathrm{S}_{5} \mathrm{O}_{6}{ }^{2-}$ & 0.07 & 0.17 & 0.18 & 0.32 & 0.47 \\
$\mathrm{~S}_{6} \mathrm{O}_{6}{ }^{2-}$ & 0.11 & 0.29 & 0.29 & 0.53 & 0.75 \\
$\mathrm{~S}_{7} \mathrm{O}_{6}{ }^{2-}$ & 0.47 & 1.03 & 1.06 & 1.68 & 2.04 \\
$\mathrm{~S}_{8} \mathrm{O}_{6}{ }^{2-}$ & 0.75 & 1.39 & 1.52 & 1.96 & 2.08 \\
$\mathrm{~S}_{9} \mathrm{O}_{6}{ }^{2-}$ & 0.90 & 1.53 & 1.50 & 1.87 & 1.79 \\
$\mathrm{~S}_{10} \mathrm{O}_{6}{ }^{2-}$ & 1.02 & 1.31 & 1.28 & 1.36 & 1.18 \\
$\mathrm{~S}_{11} \mathrm{O}_{6}{ }^{2-}$ & 0.87 & 1.32 & 1.18 & 1.12 & 0.58 \\
$\mathrm{~S}_{12} \mathrm{O}_{6}{ }^{2-}$ & 0.76 & 0.81 & 0.70 & 0.68 & 0.49 \\
$\mathrm{~S}_{13} \mathrm{O}_{6}{ }^{2-}$ & 0.59 & 0.56 & 0.49 & 0.45 & 0.35 \\
$\mathrm{~S}_{14} \mathrm{O}_{6}{ }^{2-}$ & 0.45 & 0.41 & 0.34 & 0.32 & 0.26 \\
\hline
\end{tabular}

the $\mathrm{S}_{6}, \mathrm{~S}_{7}, \mathrm{~S}_{8}$ and $\mathrm{S}_{12}$ content as compared to the freshly prepared sol (see Table III). The total $\mathrm{S}_{n}$ content $(n=6,7,8,12)$ of $20 \mathrm{ml}$ sol decreased from $22.5 \mathrm{mg}$ at $\mathrm{t}=0$ via $18 \mathrm{mg}$ after $18 \mathrm{~h}$ to $10 \mathrm{mg}$ after $45 \mathrm{~h}$. These results will be discussed below. The aging process could be greatly accelerated by addition of 2 or 3 drops of an aqueous iodine solution $\left(0.05 \mathrm{~mol}\left(\mathrm{KI}_{3}\right) / \mathrm{l}\right)$ to $1 \mathrm{ml}$ of sol: after $1-2 \mathrm{~h}$ elemental sulfur had precipitated and penta-, hexa- and some heptathionate could be detected in the aqueous phase but no or only traces of higher polythionates.

Type b) experiments allowed to study the aging process under homogeneous conditions since no precipitate was observed when Raffo sols were stirred for up to 8 days with an excess of cyclohexane. These experiments had the additional advantage, that unstable sulfur rings $\left(\mathrm{S}_{n}, n \neq 8\right)$, which decompose to $\mathrm{S}_{8}$ or polymeric sulfur in the solid state, were preserved in the organic phase and could thus be determined quantitatively.

20 or $25 \mathrm{ml}$ of Raffo sol were stirred with the tenfold volume of cyclohexane at $20^{\circ} \mathrm{C}$ for 8 days. Both phases remained clear. After certain time intervals HPLC analysis of the organic phase provided the concentrations of $S_{6}, S_{7}$ and $S_{8}$ (see Fig. 7). The only other sulfur molecule detected was $\mathrm{S}_{12}$ the concentration of which was zero within the first 5 days and reached the value of $\leqslant 0.4 \%$ by weight of the total elemental sulfur $\left(\mathrm{S}_{n}\right)$ after 8 days. The concentrations of $S_{6}, S_{7}$ and $S_{8}$ increased with time and reached some kind of equilibrium value after 8 days (see

678

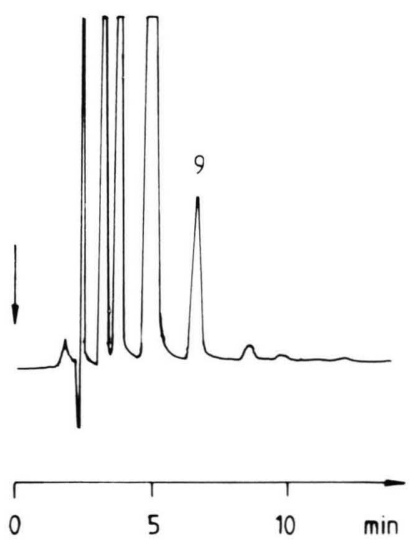

Fig. 7. HPLC analysis of the cyclohexane extract of a Raffo sol showing the presence of $\mathrm{S}_{n}$ molecules $(n=6-10)$. The first large peak represents the solvent $\mathrm{C}_{6} \mathrm{H}_{12}$. 
Table V). $20 \mathrm{ml}$ of Raffo sol contained $135.7 \mathrm{mg}$ total sulfur (see above). The amount of $\mathrm{S}_{n}$ extracted after 9 days amounted to $39.5 \mathrm{mg}$ leaving $96.2 \mathrm{mg} \mathrm{S}$ in the aqueous phase. A sulfur determination of the aqueous phase (by bromine oxidation to sulfate and titration with barium perchlorate) resulted in $95.5 \mathrm{mg} \mathrm{S}$. With other words, only $0.7 \mathrm{mg} \mathrm{S}$ had escaped the determination.

The composition of the aqueous phase was monitored by IC and it was observed that the concentra-

Table V. Concentration of sulfur rings $\mathrm{S}_{n}(\mathrm{mg} / \mathrm{l})$ in the cyclohexane phase $(200 \mathrm{ml})$ during the extraction of a Raffo sol $(20 \mathrm{ml})$ at $20^{\circ} \mathrm{C}$.

\begin{tabular}{|c|c|c|c|c|c|}
\hline $\begin{array}{l}\text { Extraction } \\
\text { time (h) }\end{array}$ & $\mathrm{S}_{6}$ & $\mathrm{~S}_{7}$ & $\mathrm{~S}_{8}$ & $\mathrm{~S}_{12}$ & $\Sigma \mathrm{S}_{n}(\mathrm{mg})$ \\
\hline 0.5 & 11.9 & 26.0 & 54.6 & 0 & 18.5 \\
\hline 19.5 & 14.6 & 31.2 & 119.6 & 0 & 33.1 \\
\hline 42.5 & 17.3 & 33.5 & 123.7 & 0 & 34.9 \\
\hline 65.0 & 19.0 & 34.9 & 126.8 & trace & 36.1 \\
\hline 89.0 & 20.8 & 36.3 & 130.9 & trace & 37.6 \\
\hline 164.5 & 22.8 & 37.7 & 136.9 & 0.3 & 39.5 \\
\hline
\end{tabular}

Table VI. Concentrations of polythionates in the aqueous phase of a Raffo sol during extraction by cyclohexane at $20{ }^{\circ} \mathrm{C}$. Given are the chromatographic peak areas in arbitrary units.

\begin{tabular}{llllll}
\hline $\begin{array}{l}\text { Extraction } \\
\text { time (d) }\end{array}$ & $\mathrm{S}_{5} \mathrm{O}_{6}{ }^{2-}$ & $\mathrm{S}_{6} \mathrm{O}_{6}{ }^{2-}$ & $\mathrm{S}_{7} \mathrm{O}_{6}{ }^{2-}$ & $\mathrm{S}_{8} \mathrm{O}_{6}{ }^{2-}$ & $\mathrm{S}_{9} \mathrm{O}_{6}{ }^{2-}$ \\
\hline 0 & 0 & 0 & 0 & 0 & 0 \\
1 & 0.44 & 0.72 & 1.73 & 1.75 & 1.24 \\
4 & 1.20 & 1.77 & 2.35 & 1.43 & 0.80 \\
7 & 1.95 & 2.56 & 2.56 & 1.42 & 0.81 \\
8 & 2.17 & 2.69 & 2.53 & 1.43 & 0.81 \\
\hline
\end{tabular}

tions of the lower polythionates $\mathrm{S}_{m} \mathrm{O}_{6}{ }^{2-}(m=5,6)$ steadily increased within 8 days, while those of hepta-, octa- and nonathionate went through maximum values, the maxima being reached as earlier as longer the sulfur chain (see Table VI).

The extractions with carbondisulfide yielded basically the same results. The $\mathrm{S}_{n}$ content of the $\mathrm{CS}_{2}$ phase increased first rapidly, later slowly, and after $162 \mathrm{~h} 47.7 \mathrm{mg} \mathrm{S}_{n}(n=6,7,8,12)$ had been extracted from $20 \mathrm{ml}$ of Raffo sol. The sulfur content of the remaining aqueous phase was determined as $88.4 \mathrm{mg}$ resulting in a total sulfur value of $136.1 \mathrm{mg}$ as compared to the $135.7 \mathrm{mg}$ expected from the $\mathrm{S}$ content of the evaporation residue. The concentrations of the polythionates in the aqueous phase changed in the very same way as in the extraction experiments with cyclohexane. In contrast to the latter, however, the $\mathrm{CS}_{2}$ phase became turbid after stirring with the sulfur sol for several days. In addition to the sulfur rings mentioned, traces of $S_{9}, S_{10}$ and $S_{11}$ could also be detected by HPLC but have not been determined.

\section{Properties of Long-Chain Polythionates}

After it had become obvious that Raffo sols contain long-chain polythionates, we found it useful to study the properties of these compounds independently. For this purpose, a polythionate mixture supposed to consist of $\mathrm{K}_{2} \mathrm{~S}_{m} \mathrm{O}_{6}$ with $15<m<40$ was prepared from potassium thiosulfate and $\mathrm{S}_{2} \mathrm{Cl}_{2}$ in concentrated hydrochloric acid following the procedure of Weitz et al. [24]. The IC analysis of the product obtained revealed the presence of $\mathrm{S}_{m} \mathrm{O}_{6}{ }^{2-}$ anions with $n=4 \cdots 18$ (see Fig. $8 \mathrm{a}$ ), longer-chain anions

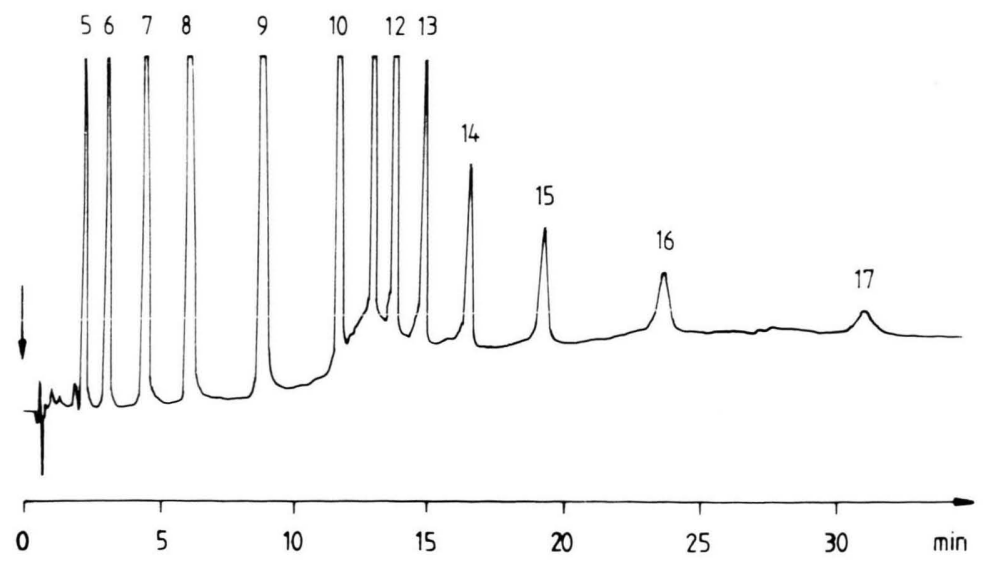

Fig. 8. Ion-chromatographic detection of the polythionates $\mathrm{S}_{m} \mathrm{O}_{6}{ }^{2-}(m=5-17)$ in " $\mathrm{K}_{2} \mathrm{~S}_{m} \mathrm{O}_{6}(15<m<40)$ " prepared after Weitz et al. [24]. Eluent: $\mathrm{CH}_{3} \mathrm{CN} / \mathrm{H}_{2} \mathrm{O}$ $(30 / 70 \mathrm{v} / \mathrm{v})$, detector wavelength $240 \mathrm{~nm}$. 


\begin{tabular}{lllllllll}
\hline $\begin{array}{l}\text { Time } \\
(\mathrm{d})\end{array}$ & $\mathrm{S}_{5} \mathrm{O}_{6}{ }^{2-}$ & $\mathrm{S}_{6} \mathrm{O}_{6}{ }^{2-}$ & $\mathrm{S}_{7} \mathrm{O}_{6}{ }^{2-}$ & $\mathrm{S}_{8} \mathrm{O}_{6}{ }^{2-}$ & $\mathrm{S}_{9} \mathrm{O}_{6}{ }^{2-}$ & $\mathrm{S}_{10} \mathrm{O}_{6}{ }^{2-}$ & $\mathrm{S}_{11} \mathrm{O}_{6}{ }^{2-}$ & $\mathrm{S}_{12} \mathrm{O}_{6}{ }^{2-}$ \\
\hline 0 & 0.56 & 0.49 & 0.82 & 1.17 & 1.14 & 0.68 & 0.83 & 0.71 \\
2 & 0.67 & 0.67 & 1.23 & 1.37 & 1.07 & 0.63 & 0.57 & 0.32 \\
7 & 0.93 & 0.99 & 1.47 & 1.04 & 0.58 & 0.25 & 0.39 & 0.07 \\
\hline
\end{tabular}

Table VII. Chromatographic peak areas (in arbitrary units) of eight polythionates as a function of the aging time $\left(20^{\circ} \mathrm{C}\right.$, aqueous solution).

were probably present too but could not be detected with the present version of our IC analysis. After standing of the solution for up to 8 days at $20^{\circ} \mathrm{C}$ the composition had changed similarly as observed for Raffo sols: the relative concentrations of $\mathrm{S}_{5} \mathrm{O}_{6}{ }^{2-}$ and $\mathrm{S}_{6} \mathrm{O}_{6}{ }^{2-}$ had increased while that of anions with more than seven sulfur atoms had decreased (Fig. 8b; Table VII).

The infrared spectrum of " $\mathrm{K}_{2} \mathrm{~S}_{m} \mathrm{O}_{6}(15<m<40)$ " shown in Fig. 3 is very similar to the one of the evaporated sol indicating that both materials mainly consist of long-chain polythionates.

Extraction of the solid salt $\mathrm{K}_{2} \mathrm{~S}_{m} \mathrm{O}_{6}(205 \mathrm{mg})$ by cyclohexane $(200 \mathrm{ml})$ for $2 \mathrm{~h}$ at $20^{\circ} \mathrm{C}$ resulted in a solution of only $2.0 \mathrm{mg} \mathrm{S}_{n}(n=6,7,8)$ as determined by HPLC. However, when $205 \mathrm{mg} \mathrm{K}_{2} \mathrm{~S}_{m} \mathrm{O}_{6}$ were dissolved in $20 \mathrm{ml} \mathrm{H}_{2} \mathrm{O}$ and the milky solution extracted by $200 \mathrm{ml}$ cyclohexane for up to 8 days, the sulfur content of the organic phase increased as follows:

\begin{tabular}{lllll}
\hline & $\mathrm{S}_{6}(\mathrm{mg})$ & $\mathrm{S}_{7}(\mathrm{mg})$ & $\mathrm{S}_{8}(\mathrm{mg})$ & total $\mathrm{S}(\mathrm{mg})$ \\
\hline 1 day & 4 & 1 & 14 & 19 \\
2 days & 8 & 5 & 49 & 62 \\
8 days & 9 & 6 & 58 & 73 \\
\hline
\end{tabular}

It is obvious that $S_{6}, S_{7}$ and $S_{8}$ are formed from $\mathrm{S}_{m} \mathrm{O}_{6}{ }^{2-}$ as will be discussed below. Except for the first measurement, the $\mathrm{S}_{6}: \mathrm{S}_{7}: \mathrm{S}_{8}$ ratio remained approximately constant during the extraction.

\section{Irradiation of Aqueous Polythionates}

Hydrophilic sulfur sols are light-sensitive [2] and direct illumination by sun-light accelerates the aging process which is characterized by sulfur precipitation and formation of short-chain polythionates [8]. To our knowledge, the photochemical decomposition of aqueous polythionates has never been investigated. Therefore, we have studied both the reaction products and the wavelength dependence of the photodecomposition of tetra- and pentathionate in water at $20{ }^{\circ} \mathrm{C}$ using a high-pressure mercury immersion lamp in combination with various optical filters $[25,26]$. Two types of experiments have been carried out. In the first type the lamp and its water-cooled jacket (made from either quartz or borosilicate glass) were immersed into the tetra- or pentathionate solution. Using the quartz jacket the aqueous phase was exposed to the full power of the lamp ( $40 \mathrm{~W}$ in the range $200-600 \mathrm{~nm}$ ) while the borosilicate glass jacket (DURAN 50) transmitted only above $290 \mathrm{~nm}$. When an aqueous solution of pure $\mathrm{K}_{2} \mathrm{~S}_{4} \mathrm{O}_{6}(477 \mathrm{mg} / \mathrm{l})$ was irradiated for $10 \mathrm{~min}$ with $200-600 \mathrm{~nm}$ radiation the solution smelled strongly after $\mathrm{H}_{2} \mathrm{~S}$, sulfur precipitated, and an IC analysis showed the presence of sulfite, thiosulfate and all polythionates $\mathrm{S}_{m} \mathrm{O}_{6}{ }^{2-}$ with $m=4-9$ (see Fig. 9). Thiosulfate was definitely the main product, and the concentrations of the polythionates decreased with increasing chain-length. About $75 \%$ of the initial $\mathrm{S}_{4} \mathrm{O}_{6}{ }^{2-}$ had disappeared. An HPLC analysis of the precipitated sulfur showed the presence of $S_{8} \gg S_{7}$, $\mathrm{S}_{6}>\mathrm{S}_{9}, \mathrm{~S}_{12}>\mathrm{S}_{10}$, the concentrations of which decreased in that order. Application of the $290-600 \mathrm{~nm}$ radiation to an aqueous $\mathrm{K}_{2} \mathrm{~S}_{4} \mathrm{O}_{6}$ solution $(410 \mathrm{mg} / \mathrm{l})$ resulted in a much slower decomposition although the same products were formed. Using empirical calibrations [19] the results in Table VIII were obtained which show that after 50 min only $40 \%$ of the initial $\mathrm{S}_{4} \mathrm{O}_{6}{ }^{2-}$ had decomposed. Thiosulfate was again the main product; the concentrations of sulfite and hepta-, octa-, and nonathionate have not been determined.

Table VIII. Photolysis of potassium tetrathionate in water at $20{ }^{\circ} \mathrm{C}$ by $290-600 \mathrm{~nm}$ radation. Initial concentration: $410 \mathrm{mg} \mathrm{S}_{4} \mathrm{O}_{6}{ }^{2-} / 1$. Concentrations in $\mathrm{mg} / \mathrm{l}$.

\begin{tabular}{lllcc}
\hline $\mathrm{t}(-\mathrm{min})$ & $\mathrm{c}\left(\mathrm{S}_{2} \mathrm{O}_{6}{ }^{2-}\right)$ & $\mathrm{c}\left(\mathrm{S}_{4} \mathrm{O}_{6}{ }^{2-}\right)$ & $\mathrm{c}\left(\mathrm{S}_{5} \mathrm{O}_{6}{ }^{2-}\right)$ & $\mathrm{c}\left(\mathrm{S}_{6} \mathrm{O}_{6}{ }^{2-}\right)$ \\
\hline 10 & 10 & 381 & 8 & 10 \\
20 & 36 & 340 & 14 & 12 \\
50 & 74 & 251 & 15 & 8 \\
\hline
\end{tabular}



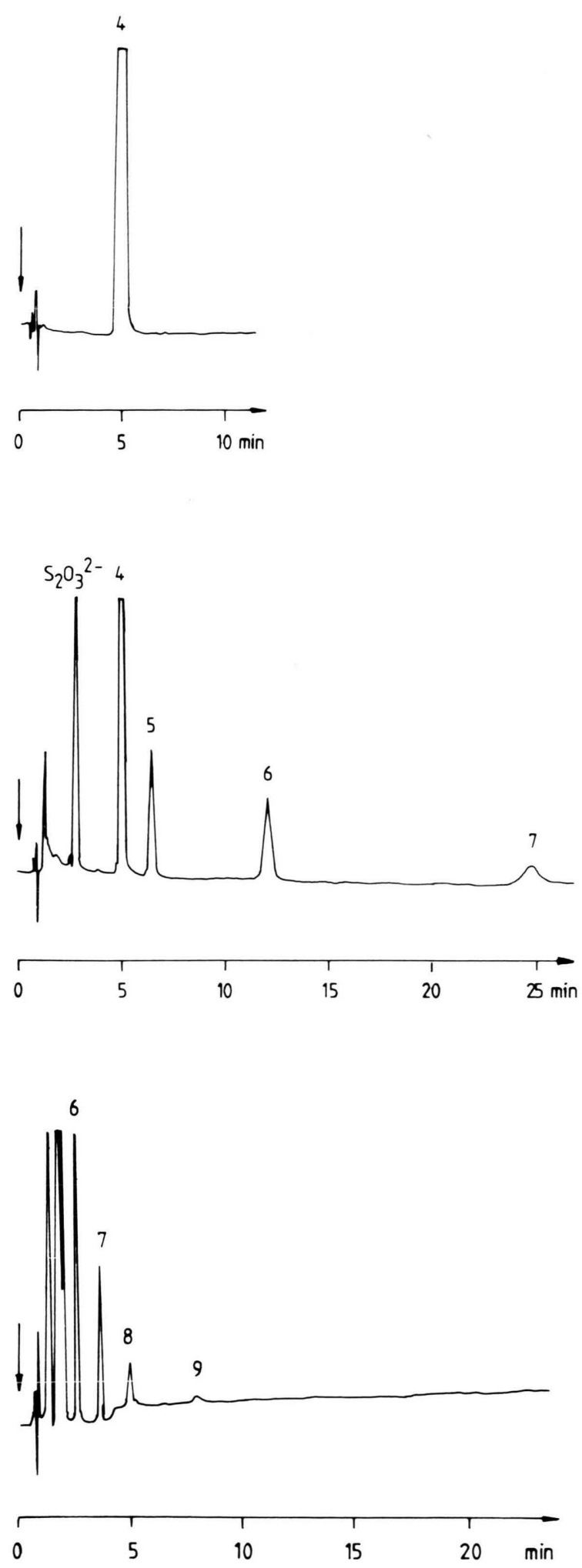

When the irradiation time was extended to $5 \mathrm{~h}$ (using the DURAN jacket) the concentrations of all higher $(m>4)$ polythionates decreased to very low values and thiosulfate also started to disappear in agreement with the well known hydrolysis of tetrathionate yielding sulfite, sulfate and elemental sulfur [27]; thiosulfate is an intermediate in this reaction [27].

The photolysis of $\mathrm{K}_{2} \mathrm{~S}_{5} \mathrm{O}_{6}$ in water $(500 \mathrm{mg} / \mathrm{l})$ applying either $200-600$ or $290-600 \mathrm{~nm}$ radiation for 10 min resulted in the same products as in the case of tetrathionate. The main products were $\mathrm{S}_{2} \mathrm{O}_{3}{ }^{2-}$ followed by $\mathrm{S}_{4} \mathrm{O}_{6}{ }^{2-}, \mathrm{S}_{5} \mathrm{O}_{6}{ }^{2-}$, and $\mathrm{S}_{6} \mathrm{O}_{6}{ }^{2-}$. Sulfite was formed too, and the precipitated sulfur consisted of $\mathrm{S}_{8}$ mainly.

The second type of experiments was supposed to demonstrate which wavelengths are effective in the decomposition of tetrathionate. In this case the lamp with quartz cooler was mounted in a horizontal metal housing. The sample contained in an Erlenmeyer flask was illuminated through a window in the lamp house. This window could be covered by optical filters (SFK 18 through 22a by Schott, Mainz) which transmit at $313,365,436,546$, and $578 \mathrm{~nm}$, respectively (halfwidths $c a .30 \mathrm{~nm}$ ). The distance from the mercury lamp to the bottom of the flask amounted to $c a$. $5 \mathrm{~cm}$. The duration of the photolysis was $1 \mathrm{~h}$ each, and IC and HPLC analyses were applied. In all experiments the tetrathionate solution $(250 \mathrm{ml}$; $525 \mathrm{mg} / \mathrm{l})$ remained clear and the temperature did not exceed $30^{\circ} \mathrm{C}$. Only with the $313 \mathrm{~nm}$ filter a slight decomposition (less than $1 \%$ ) to pentathionate could be observed. The only other decomposition product observed were traces of $\mathrm{S}_{8}$. Radiation of wavelength $>350 \mathrm{~nm}$ was completely ineffective, which can be understood from the UV absorption spectrum of aqueous $\mathrm{S}_{4} \mathrm{O}_{6}{ }^{2-}$ which shows only a very weak continuous absorbance at wavelengths of $>300 \mathrm{~nm}[28]$.

\section{Discussion}

Our results show that freshly prepared Raffo sols contain about $1125 \mathrm{mg} / \mathrm{l}$ of elemental sulfur in the form of various cyclic $\mathrm{S}_{n}$ molecules with $n=6-15$; of

Fig. 9. Formation of thiosulfate and of polythionates $\mathrm{S}_{m} \mathrm{O}_{6}{ }^{2-}(m=5-9)$ on irradiation of aqueous tetrathionate at $20{ }^{\circ} \mathrm{C}$; top: prior to irradiation, center and bottom: after irradiation (chromatographic analysis with two different eluent compositions). Ordinate: UV absorbance at $240 \mathrm{~nm}$. 
these $\mathrm{S}_{8}$ is by far the most frequent species. The solubility of orthorhombic $\alpha$-S $\mathrm{S}_{8}$ in water at $20{ }^{\circ} \mathrm{C}$ amounts to only $5 \mu \mathrm{g} / 1$ [29]. Since the elemental sulfur content of the sol is about 225,000 times this figure, this sulfur must be linked to some hydrophilic material which keeps it in solution.

The hydrophilic substance must also have a high sulfur content since only $17 \%$ of the total sulfur content of the sol $(6790 \mathrm{mg} / \mathrm{l})$ has been identified as elemental sulfur. The only compounds which can explain all the experimental facts are long-chain polythionates which in water will form globular micelles because of the hydrophobic interaction of the sulfur chain with the polar solvent resulting in the observed Tyndall beam. In these micelles the hydrophobic sulfur chains are stored in the core of the globule while the hydrophilic sulfonic acid groups will be concentrated on the surface where they are responsible for the overall hydrophilic character and the negative ionic charge of the whole globule. These globules will repell each other which stabilizes the sol, but addition of a high concentration of univalent cations like $\mathrm{Na}^{+}$(or of multivalent cations in lower concentrations $[2,9])$ will precipitate the particle as less soluble "salts". Resuspension of the sodium "salt" in an excess of water results in peptization.

It seems reasonable to assume that the amorphous sulfur-rich core of the globules dissolves a certain amount of homocyclic sulfur rings $\left(\mathrm{S}_{n}, n=6,7,8, \ldots\right)$ which in this way are kept in a liquid-like state, and therefore do not interconvert to give $\mathrm{S}_{8}$ which would easily crystallize. This sulfur mixture is protected from the attack of the surrounding water.

The surface of the micelles will be covered by a layer of water containing a certain amount of $\mathrm{H}_{3} \mathrm{O}^{+}$ or $\mathrm{Na}^{+}$cations. This structural model (Fig. 10) explains all observations reported above and in the literature.

The chemical composition of $\mathrm{Na}_{1.64} \mathrm{~S}_{34.5} \mathrm{O}_{6} \cdot 1.0 \mathrm{NaCl}$ can now be rewritten as $\mathrm{Na}_{1.64} \mathrm{~S}_{28.6} \mathrm{O}_{6} \cdot 5.9 / n \mathrm{~S}_{n} \cdot 1.0 \mathrm{NaCl}$ accounting for the $83 \%$ polythionate sulfur and $17 \%$ elemental sulfur, $\mathrm{S}_{n}$. Since the $\mathrm{NaCl}$ will be dissolved in the aqueous phase, the sol particles consist of $89.2 \% \mathrm{~S}, 3.04 \% \mathrm{Na}$, and $7.74 \% \mathrm{O}$. The "missing" $0.36 \mathrm{~mol}$ cations may be either a consequence of experimental errors or may be present as $\mathrm{H}_{3} \mathrm{O}^{+}$which would result in a hydrogen content of only $0.2 \%$ which is close to the detection limit.

The average chain length of $28.6 \mathrm{~S}$ atoms of the polythionate constituent of Raffo sols seems to be

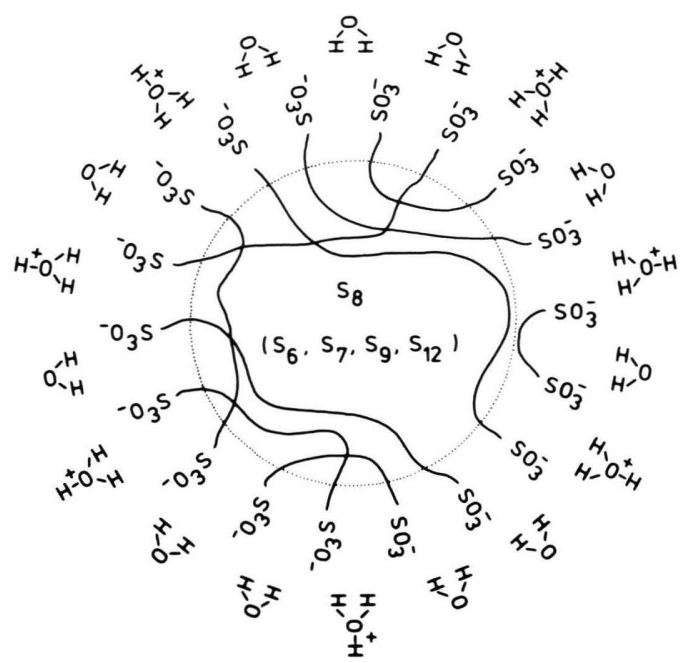

Fig. 10. Globule model of the particles in Raffo sols. The main constituents are long-chain polythionates of average chain length $m=29$, which form a micelle in the core of which elemental sulfur $\left(\mathrm{S}_{n}, n=6-12\right)$ can be dissolved. The hydrophilic surface of the globule is hydrated, and $\mathrm{H}_{3} \mathrm{O}^{+}$as well as $\mathrm{Na}^{+}$cations may be present in the water layer. The $\mathrm{S}_{n}$ molecules make up for about $17 \%$ of the total sulfur content.

sufficient to make these compounds so sparingly soluble that micelle formation takes place. These micelles are, however, not stable but slowly decompose with formation of lower polythionates (detected by IC) and more elemental sulfur (which precipitates from the solution); eq. (1):

$\mathrm{S}_{m} \mathrm{O}_{6}{ }^{2-} \rightarrow \mathrm{S}_{m-x} \mathrm{O}_{6}{ }^{2-}+\frac{x}{n} \mathrm{~S}_{n}(n>5)$

The short-chain polythionates are soluble in water and do not form micelles. Therefore, the elemental sulfur content of the sol drops (see Table III) and part of the sulfur precipitates both as rings $\mathrm{S}_{n}$ (soluble in $\mathrm{CS}_{2}$ ) and as unsoluble polymeric sulfur. This polymeric $S_{\infty}$ must be formed by decomposition of unstable $\mathrm{S}_{n}(n \neq 8)$ molecules in a secondary reaction [30] since in the presence of cyclohexane no $S_{\infty}$ is observed but all $\mathrm{S}_{n}$ species dissolve in the organic phase. It is obvious that from polythionates with 28 or more $\mathrm{S}$ atoms small and large rings $\mathrm{S}_{n}(n=6 \cdots 17)$ and short-chain as well as medium-sized polythionates $\mathrm{S}_{m} \mathrm{O}_{6}{ }^{2-}(m=5 \cdots 14)$ will be formed by reaction (1), as have in fact been detected by HPLC and IC, respectively. This decomposition (disproportionation) will be catalyzed by traces of nucleophiles like 
$\mathrm{HS}^{-}$or $\mathrm{S}_{2} \mathrm{O}_{3}{ }^{2-}$ which may be formed by the slow hydrolysis of the polythionates [27]:

$$
\begin{aligned}
& { }^{-} \mathrm{O}_{3} \mathrm{~S}-\mathrm{S}_{x}-\mathrm{SO}_{3}{ }^{-}+\mathrm{H}_{2} \mathrm{O} \rightarrow \mathrm{HSO}_{4}{ }^{-}+\mathrm{HS}_{x}-\mathrm{SO}_{3}{ }^{-} \\
& \mathrm{HS}_{x}-\mathrm{SO}_{3}{ }^{-} \rightarrow \frac{x}{n} \mathrm{~S}_{n}+\mathrm{HSO}_{3}{ }^{-}(n>5) \\
& \mathrm{HS}_{x}-\mathrm{SO}_{3}{ }^{-} \rightarrow \frac{x-1}{n} \mathrm{~S}_{n}+\mathrm{S}_{2} \mathrm{O}_{3}{ }^{2-}+\mathrm{H}^{+}(n>5) \\
& 2 \mathrm{HS}_{x}-\mathrm{SO}_{3}{ }^{-} \rightarrow \mathrm{H}_{2} \mathrm{~S}+{ }^{-} \mathrm{O}_{3} \mathrm{~S}-\mathrm{S}_{2 x-1}-\mathrm{SO}_{3}{ }^{-}
\end{aligned}
$$

Equations (2), (3) and (4) provide an alternative route for the disproportionation of polythionates with formation of elemental sulfur [31], but reaction (2) is known to be slow at $20^{\circ} \mathrm{C}$ [27]. The mechanistic implication of reactions like (1) and (3) have been discussed elsewhere [32, 33].

It has been reported [34], that freshly prepared Raffo sols do not consume iodine, while after aging a considerable iodine consumption can be observed. Reactions (2) through (5) provide an explanation since a number of reduced sulfur compounds are formed which all are oxidized by $\mathrm{I}_{2}$ in water at $20^{\circ} \mathrm{C}$. Sulfanemonosulfonic acids $\mathrm{HS}_{x} \mathrm{SO}_{3} \mathrm{H}$ are oxidized by $\mathrm{I}_{2}$ to give polythionates $\mathrm{S}_{2 x}\left(\mathrm{SO}_{3} \mathrm{H}\right)_{2}$ [35]. However, iodine may also oxidize lower polythionates more rapidly to sulfate than long-chain anions.

If equation (1) is a major decomposition reaction for long-chain polythionates, then species with less than six sulfane sulfur atoms should accumulate because of the thermodynamic instability of $\mathrm{S}_{n}$ molecules with $n<6$. This is exactly what has been observed: the concentration of $\mathrm{S}_{5} \mathrm{O}_{6}{ }^{2-}$ and $\mathrm{S}_{6} \mathrm{O}_{6}{ }^{2-}$ increase on aging, while long-chain species decrease. Medium-sized anions first increase, too, but later seem to be destroyed by reactions of type (6), which also favor the accumulation of short-chain species since only $\mathrm{S}_{m+x} \mathrm{O}_{6}{ }^{2-}$ with $m+x>8$ will enter reaction (1):

$$
2 \mathrm{~S}_{m} \mathrm{O}_{6}{ }^{2-} \rightarrow \mathrm{S}_{m-x} \mathrm{O}_{6}{ }^{2-}+\mathrm{S}_{m+x} \mathrm{O}_{6}{ }^{2-}
$$

In the presence of water cyclooctasulfur dissolved in organic solvents is in equilibrium with about $0.8 \%$ $\mathrm{S}_{7}$ and $0.3 \% \mathrm{~S}_{6}$ at $20{ }^{\circ} \mathrm{C}[36]$ :

$$
\mathrm{S}_{8} \rightleftharpoons \frac{8}{7} \mathrm{~S}_{7} \rightleftharpoons \frac{4}{3} \mathrm{~S}_{6}
$$

However, the $\mathrm{S}_{6} / \mathrm{S}_{8}$ and $\mathrm{S}_{7} / \mathrm{S}_{8}$ ratios observed in this work are much higher and show that the mentioned equilibrium (7) is established slowly. In particular the elemental sulfur dissolved in the hydrophobic core of the micelles is surprizingly rich in $\mathrm{S}_{6}$ and $\mathrm{S}_{7}\left(\mathrm{~S}_{6}: \mathrm{S}_{8}=\right.$ $0.22 ; \mathrm{S}_{7}: \mathrm{S}_{8}=0.36$ by weight; see Table III). The evaporation residue also contains much more $\mathrm{S}_{n}$ $(n \neq 8)$ molecules as what might have been expected from the instability of these species. It is therefore not surprizing that hydrophilic sulfur sols are much more reactive than pure finely divided $\mathrm{S}_{8}$ since both $\mathrm{S}_{n}(n \neq 8)$ and $\mathrm{S}_{m} \mathrm{O}_{6}{ }^{2-}$ species are more reactive than $\mathrm{S}_{8}$. On prolonged aging or drying or heating the unstable species decompose and finally only $\alpha-\mathrm{S}_{8}$ as well as some lower polythionates $(m=4,5)$ will be left as the dominating compounds.

\section{Nature of the "Elemental Sulfur" $\left(\mathrm{S}^{0}\right)$ Produced by Certain Sulfur Bacteria}

It has been known for more than 100 years [37] that certain sulfur bacteria living in aquatic environments containing sulfide $\left(\mathrm{HS}^{-}\right)$, thiosulfate, or tetrathionate under certain conditions produce sulfur-like transparent droplets ("globules") which are stored within or outside the bacterial cell [38]. For photographs of sulfur-containing bacteria see, for instance, ref. [39-43]. These droplets reach diameters of up to $1 \mu \mathrm{m}[38,42,43]$ and seem to consist of sulfur in the zero oxidation state $\left(\mathrm{S}^{0}\right)$, but the exact molecular nature has long been unknown. The spherical or ellipsoidal globules $[38,42-44]$ are at least partly soluble in acetone, chloroform, ethanol, and carbondisulfide [44-47], are of white or pale-yellow color [37], show a high index of refraction [39-43], and have been described as liquid-like [39] and amorphous (no X-ray diffraction) [39]. When allowed to stand in the wet state [39] or on drying [48] these sulfur globules eventually convert into crystalline $\alpha-\mathrm{S}_{8}$.

Very recently we have shown by HPLC and IC analysis that the extracellular sulfur globules produced by Thiobacillus ferrooxidans have a micelle structure very similar to the Raffo sols; these globules contain $\mathrm{S}_{8}, \mathrm{~S}_{6}, \mathrm{~S}_{7}, \mathrm{~S}_{9}$, and $\mathrm{S}_{12}$ as well as polythionates $\mathrm{S}_{m} \mathrm{O}_{6}{ }^{2-}$ with $m$ ranging from 4 to 17 [20]. For the following reasons we believe that a similar elemental sulfur-polythionate micelle structure can also be assumed for the globules produced by certain other bacteria living in neutral or acidic environments:

a) Polythionates have been detected in the media of many Thiobacilli species $[49,50]$ as well as in media of Chlorobium vibrioforme $f$. thiosulfatophilum [51] and Chlorobium limicola thiosulfatophilum 6230 [52].

b) The globules show a high sulfur content but do not crystallize for hours at $20^{\circ} \mathrm{C}$ in the presence of water. Therefore, they cannot be liquid sulfur 
which despite its tendency to supercooling is not stable at $20^{\circ} \mathrm{C}$. Only a mixture in which $\mathrm{S}_{8}$ is not dominating will remain liquid at $20^{\circ} \mathrm{C}$ for longer periods of time.

c) The globules have been described as pale-yellow or white which fits the properties of Raffo sol particles whereas supercooled liquid sulfur is of deepyellow color.

d) Liquid sulfur is an extremely hydrophobic material while bacterial sulfur globules are hydrophilic [40] like Raffo sol particles. Hydrophilic properties and a high sulfur content can only be realized by a long sulfur chain with polar end groups as in polythionate anions.

e) On drying or aging sulfur globules crystallize partly as $\alpha-\mathrm{S}_{8}[39,48]$ as do Raffo sols.

f) The density of sulfur globules produced by two types of Chromatium has been determined as $1.22 \mathrm{~g} \cdot \mathrm{cm}^{-3}$ [47] which is much lower than the density of liquid sulfur (extrapolated to $20^{\circ} \mathrm{C}$ ) of $1.85 \mathrm{~g} \cdot \mathrm{cm}^{-3}$. The micelle structure with an electrical double layer on the surface and a relatively high water content is qualitatively in agreement with the experimental density.

g) It has been observed [53] that sulfur $\left(S^{0}\right)$ produced by Thiobacillus denitrificans does not move in electrophoresis experiments. This can be explained by the very high molecular weight of hydrophilic sol particles compared with the molecular mass of the short-chain polythionats like $\mathrm{S}_{4} \mathrm{O}_{6}{ }^{2-}$ which were used as reference materials [53]. The same authors found that the $\mathrm{S}^{\circ}$ decomposed in the presence of iodine with formation of soluble polythionates which is exactly the behavior of Raffo sol particles as described above.

h) Long-chain polythionates will react with cyanide in a similar way as elemental sulfur and will also exhibit a strong UV absorption. This can be expected from the corresponding reactions [54] and the UV spectra [28] of $\mathrm{S}_{4} \mathrm{O}_{6}{ }^{2-}, \mathrm{S}_{5} \mathrm{O}_{6}{ }^{2-}$, and $\mathrm{S}_{6} \mathrm{O}_{6}{ }^{2-}$ :

$$
\begin{aligned}
& \mathrm{S}_{x} \mathrm{O}_{6}{ }^{2-}+(x-3) \mathrm{CN}^{-}+\mathrm{H}_{2} \mathrm{O} \rightarrow \\
& \mathrm{S}_{2} \mathrm{O}_{3}{ }^{2-}+(x-3) \mathrm{SCN}^{-}+\mathrm{H}_{2} \mathrm{SO}_{4}
\end{aligned}
$$

Both types of compounds may therefore easily be mistaken for each other expecially in complex mixtures.

i) It may seem a contradiction that bacterial $S^{0}$ dissolves in $\mathrm{CS}_{2}$ while long-chain polythionates do not. However, it has been observed by many microbiologists that the $\mathrm{CS}_{2}$ extraction of $\mathrm{S}^{0}$ is dif- ficult and takes many hours which is understandable since the aging process is slow (see Table V). Only the $\mathrm{S}_{n}$ molecules produced will dissolve in $\mathrm{CS}_{2}$ while the lower polythionates remain in the aqueous phase.

The formation of long-chain polythionates in bacteria and in Raffo sols most probably proceeds by reactions of the following type $[31,56]$ :

$$
\begin{aligned}
& n \mathrm{~S}_{2} \mathrm{O}_{3}{ }^{2-}+(n+1) \mathrm{H}^{+} \rightarrow \mathrm{HS}_{n} \mathrm{SO}_{3}{ }^{-}+n \mathrm{HSO}_{3}{ }^{-} \\
& 2 \mathrm{HS}_{n} \mathrm{SO}_{3}{ }^{-} \rightarrow \mathrm{H}_{2} \mathrm{~S}+\mathrm{S}_{2 n+1} \mathrm{O}_{6}{ }^{2-} \\
& \mathrm{S}_{m} \mathrm{O}_{6}{ }^{2-}+n \mathrm{~S}_{2} \mathrm{O}_{3}{ }^{2-} \rightarrow \mathrm{S}_{m+n} \mathrm{O}_{6}{ }^{2-}+n \mathrm{SO}_{3}{ }^{2-}
\end{aligned}
$$

Reaction (11) is reversible and can be used to reduce the particle size of Raffo sols by treatment with sulfite [55]; is may also serve for the re-activation of the $S^{0}$ sulfur in bacteria since it transforms poorly soluble higher polythionates in better soluble smaller anions.

The so far only poorly characterized sulfanemonosulfonic acids $\mathrm{HS}_{n} \mathrm{SO}_{3} \mathrm{H}$ [35] obviously are key intermediates and should therefore be studied carefully in the future.

\section{Experimental}

\section{Materials}

The reference materials $\mathrm{K}_{2} \mathrm{~S}_{3} \mathrm{O}_{6}$ [57], $\mathrm{K}_{2} \mathrm{~S}_{4} \mathrm{O}_{6}$ [57], $\mathrm{K}_{2} \mathrm{~S}_{5} \mathrm{O}_{6}$ [57], and $\mathrm{K}_{2} \mathrm{~S}_{6} \mathrm{O}_{6}$ [57] were prepared by published procedures (and their purity checked by infrared spectroscopy) using $\mathrm{SCl}_{2}$ (freshly distilled with addition of $\mathrm{PCl}_{3}$ [57]), $\mathrm{K}_{2} \mathrm{~S}_{2} \mathrm{O}_{3}$ (Fluka, purum), $\mathrm{Na}_{2} \mathrm{~S}_{2} \mathrm{O}_{3} \cdot 5 \mathrm{H}_{2} \mathrm{O}$ (Merck, reinst), $\mathrm{S}_{2} \mathrm{Cl}_{2}$ (techn.), and aqueous $\mathrm{HCl}(36 \%$, Fluka, analytical grade). All organic solvents were distilled from drying agents: $\mathrm{CCl}_{4}\left(\mathrm{P}_{4} \mathrm{O}_{10}\right), \quad \mathrm{CH}_{3} \mathrm{OH}\left(\mathrm{MgSO}_{4}\right), \quad \mathrm{CS}_{2}\left(\mathrm{P}_{4} \mathrm{O}_{10}\right) ; \mathrm{C}_{6} \mathrm{H}_{12}$ was of analytical grade.

\section{Methods}

The equipment used for IC [19, 20], HPLC [17, 18, 30] and Raman spectroscopy [58] as well as the photolysis apparatus $[15,26]$ have been described elsewhere. Infrared spectra were recorded by a Perkin-Elmer $580 \mathrm{~B}$ grating spectrometer $\left(180-5000 \mathrm{~cm}^{-1}\right)$ equipped with data processing terminal. The centrifuge operated at 5200 r.p.m. (9000 g).

Solutions analyzed by IC or HPLC were filtered through an Acro LC 13 filter $(0.45 \mu \mathrm{m})$. To further protect the chromatographic column used for the IC analysis both a solvent saturation column $(1=10 \mathrm{~cm}$; installed before the loop injector) and a guard-column (after the injector) were used; both columns 
contained the same Spher C 18 material as the separation column. Acetonitrile concentrations of either 22 or $30 \%$ by volume were applied; the UV detector operated at a wavelength of $240 \mathrm{~nm}$. When sulfur sols after aging were injected for IC analysis it was occasionally observed that the peaks due to penta- till octathionate split into two peaks (see, for instance, Fig. 1b). Sometimes the second peaks showed up as shoulders only. These additional peaks at higher retention times disappeared when the sol was diluted (1:5) prior to analysis. Obviously, overloading of the column by too high a total concentration of polythionate is responsible for the observed peak splittings. Furthermore, the retention times of the polythionates turned out to depend on the sample concentration. Dilution by water (doubly distilled) resulted in an increase of the retention time. Reference and sample concentrations should therefore not be too different.

We are grateful to the Deutsche Forschungsgemeinschaft and the Verband der Chemischen Industrie for continuing support, and to Mrs. K. Thiel for typing the many versions of the manuscript to this paper.
[1] Sulfur Compounds, Part 112; for Part 111 see R. Steudel and E.-M. Strauss, in D. Sowerby and L. Haiduc (eds): The Chemistry or Inorganic Homoand Heterocycles, Vol. 2, p. 769, Chapter 28, Academic Press, London (1987).

[2] For excellent summaries of the older literature see Gmelin Handbuch der Anorgansichen Chemie, 8. Auflage, Schwefel, Teil A, Lieferung 2, p. 486-501, Verlag Chemie, Weinheim (1953); S. Odén, Der Kolloide Schwefel, Nova Acta Regiae Soc. Sci. Upsaliensis, Ser. IV, Vol. 3, Nr. 4, Upsala (1913).

[3] Review: Gmelin Handbuch der Anorganischen Chemie, 8. Auflage, Schwefel, Teil B, Lieferung 2, p. 374-394, Verlag Chemie, Weinheim (1960).

[4] R. Engel, C. R. Hebd. Scean, Acad. Sci. 112, 866 (1891).

[5] A. H. W. Aten, Z. Phys. Chem. 88, 321 (1914).

[6] P. Bartlett and W. R. Roderick, Inorg. Synth. 8, 100 (1966).

[7] R. Steudel and H.-J. Mäusle, Z. Anorg. Allg. Chem. 457, 165 (1979).

[8] H. Bassett and R. G. Durrant, J. Chem. Soc. 1931, 2919.

[9] E. O. K. Verstraete, Kolloid-Z. 102, 251 (1943).

[10] F. H. Pollard, G. Nickless, and R. B. Glover, J. Chromatogr. 15, 518 (1964); E. Blasius and R. Krämer, Z. Anorg. Allg. Chem. 318, 113 (1962).

[11] E. Weitz and K. Spohn, Chem. Ber. 89, 2332 (1956).

[12] M. Raffo, Kolloid-Z. 2, 358 (1907).

[13] E. M. Zaiser and V. K. LaMer, J. Colloid Sci. 3, 571 (1948); V. K. LaMer and I. Johnson, J. Am. Chem. Soc. 67, 2055 (1945); A. S. Kenyon and V. K. LaMer, J. Colloid Sci. 4, 163 (1948).

[14] M. Kerker, E. Daby, G. L. Cohen, J. P. Kratohvil, and E. Matijević, J. Phys. Chem. 67, 2105 (1963).

[15] T. Svedberg, Kolloid-Z. 4, 49 (1909).

[16] E. Weitz, K. Gieles, J. Singer, and B. Alt, Chem. Ber. 89, 2365 (1956).

[17] R. Steudel, H.-J. Mäusle, D. Rosenbauer, H. Möckel, and T. Freyholdt, Angew. Chem. 93, 402 (1981); Angew. Chem., Int. Ed. Engl. 20, 394 (1981).

[18] R. Strauss and R. Steudel, Fresenius, Z. Anal. Chem. 326, 543 (1987).

[19] R. Steudel and G. Holdt, J. Chromatogr. 361, 379 (1986).
[20] R. Steudel, G. Holdt, Th. Göbel, and W. Hazeu, Angew. Chem. 99, 143 (1987); Angew. Chem., Int. Ed. Engl. 26, 151 (1987).

[21] M. Schmidt and T. Sand, J. Inorg. Nucl. Chem. 26, 1179 (1964).

[22] R. Steudel and H.-J. Mäusle, Z. Naturforsch. 33a, 951 (1978) and references cited therein.

[23] B. Meyer and M. Ospina, Phosphorus Sulfur 14, 23 (1982).

[24] E. Weitz, F. Becker, K. Gieles, and B. Alt, Chem. Ber. 89, 2353 (1956); E. Weitz, K. Spohn, J. Singer, F. Becker, and K. Gieles, Angew. Chem. 64, 166 (1952).

[25] R. Steudel, G. Holdt, and A. T. Young, J. Geophys. Res. 91, 4971 (1986).

[26] E.-M. Strauss and R. Steudel, Z. Naturforsch. 42b, 682 (1987).

[27] B. Meyer and M. Ospina, Phosphorus Sulfur 14, 23 (1982).

[28] M. Schmidt and T. Sand, J. Inorg. Nucl. Chem. 26, 1173 (1964).

[29] J. Boulege, Phosphorus Sulfur 5, 127 (1978).

[30] R. Steudel, S. Paßlack-Stephan, and G. Holdt, Z. Anorg. Allg. Chem. 517, 7 (1984).

[31] R. E. Davis, J. Am. Chem. Soc. 80, 3565 (1958).

[32] R. Steudel, Nova Acta Leopoldina NF 59, 231 (1985).

[33] R. S. Laitinen, T. A. Pakkanen, and R. Steudel, J. Am. Chem. Soc. 109, 710 (1987).

[34] W. Pauli, E. Russer, and P. Balog, Helv. Chim. Acta 27, 585 (1944).

[35] M. Schmidt, Z. Anorg. Allg. Chem. 289, 158 (1957).

[36] F. N. Tebbe, E. Wasserman, W. G. Peet, A. Vatvars, and A. C. Hayman, J. Am. Chem. Soc. 104, 4971 (1982).

[37] S. Winogradsky, Bot. Ztg. 31, 489 (1887); F. Cohn, Beitr. Biol. Pflanzen 1, 141 (1875).

[38] H. G. Schlegel, Allgem. Mikrobiologie, 5. Auflage, Thieme, Stuttgart (1981).

[39] G. J. Hageage, E. D. Eanes, and R. L. Gherna, J. Bacteriol. 101, 464 (1970).

[40] G. L. Nicolson and G. L. Schmidt, J. Bacteriol. 105, 1142 (1971).

[41] J. F. Imhoff and H. G. Trüper, Zbl. Bakt., I. Abt. Orig. C $1,1980,61$.

[42] N. H. Lawry, V. Jani, and Th. E. Jensen, Curr. Microbiol. 6, 71 (1981). 
[43] W. R. Strohl, I. Geffers, and J. M. Larkin, Curr. Microbiol. 6, 75 (1981).

[44] G. L. Schmidt and M. D. Kamen, Arch. Microbiol. 73, 1 (1970).

[45] G. L. Schmidt, G. L. Nicolson, and M. D. Kamen, J. Bacteriol. 105, 1137 (1971). In this paper the sulfur content of globules was determined from the absorbance at $264 \mathrm{~nm}$ in ethanol solution assuming that elemental sulfur $\left(\mathrm{S}_{8}\right)$ was present as the only UV absorbing species.

[46] H. Troelsen and B. B. Jorgensen, Estuarine, Coastal, Shelf Sci. 15, 255 (1982).

[47] R. Guerrero, J. Mas, and C. Pedrós-Alió, Arch. Microbiol. 137, 350 (1984).

[48] H. G. Trüper and J. C. Hatheway, Nature 215, 435 (1967) and references cited therein.

[49] P. A. Trudinger, Rev. Pure Appl. Chem. 17, 1 (1967).

[50] D. P. Kelly, Philos. Trans. R. Soc. London, Ser. B 298, 499 (1982); Microbiol. Sci. 2, 105 (1985).
[51] R. Steudel, G. Holdt, Th. Göbel, and U. Fischer, unpublished results.

[52] R. Steudel, G. Holdt, Th. Göbel, M. Hipp, and H. G. Trüper, unpublished results.

[53] M. Aminuddin and D. J. D. Nicholas, Biochim. Biophys. Acta 325, 81 (1973).

[54] O. A. Nietzel and M. A. DeSesa, Anal. Chem. 27, 1839 (1953); A. Kurtenacker and K. Bittner, Z. Anorg. Allg. Chem. 142, 119 (1924).

[55] G. W. Donaldson and F. J. Johnston, J. Phys. Chem. 73, 2064 (1969).

[56] O. Foss and I. Kringlebotn, Acta Chem. Scand. 15, 1608 (1961); F. Foerster and K. Centner, Z. Anorg. Allg. Chem. 157, 45 (1926).

[57] F. Fehér, in G. Brauer (ed.): Handbuch der Präparativen Anorganischen Chemie, 3rd edit. Vol. I, p. 380, 397-402, F. Enke Verlag, Stuttgart (1975).

[58] R. Steudel, D. Jensen, and B. Plinke, Z. Naturforsch. 42b, 163 (1987). 